Illinois State University

ISU ReD: Research and eData

Theses and Dissertations

5-23-2021

\title{
Treasure, Women, and Agency: Exploring Objectification in a World of Living Objects
}

Alexa Parker

Illinois State University, alexaparker209@gmail.com

Follow this and additional works at: https://ir.library.illinoisstate.edu/etd

\section{Recommended Citation}

Parker, Alexa, "Treasure, Women, and Agency: Exploring Objectification in a World of Living Objects" (2021). Theses and Dissertations. 1460.

https://ir.library.illinoisstate.edu/etd/1460

This Thesis is brought to you for free and open access by ISU ReD: Research and eData. It has been accepted for inclusion in Theses and Dissertations by an authorized administrator of ISU ReD: Research and eData. For more information, please contact ISUReD@ilstu.edu. 


\title{
TREASURE, WOMEN, AND AGENCY: EXPLORING OBJECTIFICATION IN A WORLD OF LIVING OBJECTS
}

\begin{abstract}
ALEXA PARKER
70 Pages

This thesis examines the poems Beowulf and Judith with a focus on the ways in which peaceweavers and treasure objects are portrayed. In Old English texts, such as Beowulf, peaceweaving women have been compared to treasure, with claims that peaceweavers act in the same way and perform the same duties as objects of exchange: they bring peace between men. By using an object-oriented perspective to examine the relationships between these agentive objects and the women objectified as such, I argue that a more nuanced understanding of women's agency and power in early medieval England can be reached. If early medieval English women are objectified, they may also be interpreted as having agency (and power) on levels comparable to these objects, and thus challenge that of men. Thus, in my thesis, I seek to answer the following question: What does it mean for a woman to be objectified if the object is agentive?
\end{abstract}

KEYWORDS: Old English Literature; Early Medieval England; Object-Oriented Ontology; Beowulf; Peaceweaving; Peaceweaver 
TREASURE, WOMEN, AND AGENCY: EXPLORING OBJECTIFICATION IN A WORLD

OF LIVING OBJECTS

\author{
ALEXA PARKER
}

A Thesis Submitted in Partial

Fulfillment of the Requirements

for the Degree of

MASTER OF ARTS

Department of English

ILLINOIS STATE UNIVERSITY

2021 
(C) 2021 Alexa Parker 
TREASURE, WOMEN, AND AGENCY: EXPLORING OBJECTIFICATION IN A WORLD

OF LIVING OBJECTS

ALEXA PARKER

COMMITTEE MEMBERS:

Susan M. Kim, Chair

K Aaron Smith 


\section{ACKNOWLEDGMENTS}

I owe a deep thanks to Dr. Susan Kim, my advisor, committee chair, and mentor for her dedicated pedagogy, encouragement, and support. I cannot thank her enough for the many times she has patiently advised me over the years, always leading by example to help me become a better student and researcher. Without her, this thesis would have never come to fruition. I would also like to thank Dr. K Aaron Smith for sharing his extensive knowledge of the English language and linguistics. He was instrumental in answering crucial questions for this thesis, providing both sources and methodologies that supported and strengthened my arguments.

In addition to my committee members, I would like to thank my friends and family for always supporting my work. To my parents, thank you for always checking-in how my thesis was going, even if you weren't quite sure what it was about or what all was involved. Mom, thank you for always following up in an attempt to understand those parts, too. Thank you to Thelma, who always acted as a listening ear for my ideas, consistently providing thoughtful feedback and excellent suggestions in return, as well as non-academic friendship when needed (a contribution not to be underestimated!). And, to my fiancé, Joe: thank you for always supporting me, reminding me both to do my work and to stop working (somehow always knowing exactly when either was needed), and for never failing to pick up extra chores when I couldn't keep up. Your love, kindness, and patience made this thesis possible.

A.P. 


\section{CONTENTS}

Page

ACKNOWLEDGMENTS

$\begin{array}{lll}\text { FIGURES } & \text { iii }\end{array}$

$\begin{array}{ll}\text { INTRODUCTION } & 1\end{array}$

CHAPTER I: WOMEN AS TREASURE: PEACEWEAVING WIVES VERSUS

PEACEMAKING OBJECTS

CHAPTER II: TREASURE AS BEING: OBJECT ORIENTED ONTOLOGY AND OLD

$\begin{array}{lr}\text { ENGLISH LITERATURE } & 20\end{array}$

CHAPTER III: WHEN PEACEKEEPING FAILS: EXPRESSIONS OF ANXIETY OVER

POWERFUL OBJECTS AND POWERFUL WOMEN 42

$\begin{array}{ll}\text { CONCLUSION } & 62\end{array}$

$\begin{array}{ll}\text { WORKS CITED } & 67\end{array}$ 


\section{FIGURES}

Figure $\quad$ Page

$\begin{array}{ll}\text { 1. Desborough Necklace } & 6\end{array}$

2. Gold Ring $\quad 7$

3. Duke William's daughter Aelfgyve is promised in marriage to King Harold II 8 


\section{INTRODUCTION}

In studies of Old English texts that include female characters, such as Beowulf, the women are often focused on for their roles as peaceweavers in the story. This peaceweaving role has been compared in terms of function to the role of treasure - women as peaceweavers act in the same way and perform the same duties as objects of exchange (treasure); they bring peace between men. In these conversations about peaceweavers as treasure, peaceweaving women can be interpreted as passive objects to be exchanged, with their only way of regaining agency being by actively stepping out of that role. However, in many locations throughout Old English literature, there are areas in which objects are represented as in possession of powerful agency, often comparable to that of the men (who are almost always seen as powerfully agentive) of these texts. Thus, in this project I aim to examine the agency of peaceweaving women through the lens of Object-Oriented Ontology, which posits that objects have agency. If early medieval English women are objectified, they may also be interpreted as having agency (and power) on levels comparable to these objects, and thus comparable to that of men. Thus, in this thesis, I seek to answer the following question: What does it mean for a woman to be objectified if the object is agentive?

The primary texts I will be focusing on are Beowulf and Judith. These two texts are bound in the Nowell Codex, the second of two collections in the Cotton MS Vitellius A XV volume held and digitized by the British Library. Together, these two texts reveal important connections among women, treasure, and agency. For the purposes of this project, Beowulf is important as the main text in which both peaceweaving women and agentive objects are represented. Additionally, the importance of exchange to maintain peace is a key theme in Beowulf, and the poem engages explicitly with the politics of exchanging women and 
exchanging trade objects. In the text of Judith, I will argue that there are ways in which these themes brought forth in Beowulf (women as objects of exchange, objects having agency, and the peacemaking behaviors of objects and women) come together in the character of Judith. Judith acts as both a peaceweaver and a warrior. In her, we see the embodiment of the objectified peaceweaver as a powerful agent.

In my first chapter, I investigate the connection between peaceweaving women and objects of exchange, specifically treasure. I further elucidate the connections brought forth by Christopher Fee by drawing on material evidence of gold worn by wealthy women in early medieval England, both through preserved artifacts and through Gale Owen-Crocker's research in Dress in Anglo-Saxon England. Through these connections, I establish the importance of the roles both treasure and peaceweavers played in early medieval England, and why goldadornment would be used most specifically as a marker of the role peaceweaving women played.

In my second chapter, I move into establishing treasure as an agentive object. To do this, I examine the usefulness of Object-Oriented Ontology in early medieval English literature by examining how it creates meaning in Riddle 60 of the Exeter Book. Without the consent and agency of both the non-human objects and the human maker in the creation of the runic text, the runic text would not serve its purpose; it would not carry the intended message. In Beowulf, I examine a similar effect with the weapons, armors, and other treasures Beowulf must use in his battles. I support these arguments by examining instances in which objects seem to be represented as agentive with attention to the typology of verbs and semantic role theory. Through these linguistic perspectives, it can be seen that there is a possibility for objects being recognized as agentive, rational, animate subjects. Finally, I examine treasure having agency outside of the 
use of mankind: treasure "eldum swa unnyt swa hyt æror wæs" [to men as useless as it previously was] (Beowulf line 3170).

In the final chapter, I seek to answer what it means for peaceweaving women to be objectified as objects of exchange if those objects have agency. I discuss the parallels between objects' existence outside of the use of man and the effects they render on the world even when not being used by men and between women's existence outside of the realm of men and the ways in which, independent of men, they wielded power and performed actions that had consequences. However, I also examine the anxiety these conclusions bring, regarding both powerful objects and powerful women. Finally, I examine the role Judith plays within the poem Judith, as she is a representation of the combination of treasure and peaceweaver and the power which together they can hold. As the place where peacemaking object and peaceweaving women meet, she becomes a leader of men. 


\section{CHAPTER I: WOMEN AS TREASURE: PEACEWEAVING WIVES VERSUS}

\section{PEACEMAKING OBJECTS}

"Sio gehaten is, / geong goldhroden, gladum suna Frodan" [She is promised, young and adorned with gold, to the cheerful son of Froda] (Beowulf Lines 2027-28). This scene describes Freawaru, a young bride in Beowulf, but really it could be describing any of the women featured in the text. The women in the Old English text Beowulf are almost all described as "adorned with gold" or "ring adorned," like shining treasures to be exchanged. These women were

peaceweavers, queens who were noblewomen married into a family to preserve peace between her male relatives and husband, and often, if the peace was lost, these women were considered failures: an inevitable fate in a society in which "Oft seldan hwær / æfter leodhryre lytle hwile / bongar bugeð, peah seo bryd duge" [Continually, seldom anywhere after the death of a leader does the deadly spear rest even a little while, though the bride is good] (Beowulf Lines 2032-34). In his article "“Beag and Beaghroden' Women, Treasure, and the Language of Social Structure in 'Beowulf" Christopher Fee argues there is a clear connection in Beowulf between peaceweavers and treasure through language such as goldhroden (gold-adorned) and beaghroden (ringadorned). Those overlapping descriptions of treasure and the women of Beowulf, Fee argues, mark the women of Beowulf as treasure objects to be exchanged.

However, the connection is clear not only in language but also in material. T.F. Martin theorizes that "dress constructs social perceptions of the body and is therefore intimately involved in the experience and embodiment of identity" (28). The results of this idea are important in the context of this chapter - for the Beowulf poet's representation of the noble peaceweavers within the poem was likely shaped by the dress of actual women and the associated experiences and embodiments of their identities. Thus, in this chapter I will draw on 
both the language and the material associated with peaceweaving women and treasure objects to establish the parallel function of peaceweaving wives and peacemaking objects within early medieval English literature and, more broadly, culture. I will be focusing on the $8^{\text {th }}$ through $11^{\text {th }}$ centuries in England, as this is when it has been estimated that Beowulf was developed (likely first as an oral performance and then eventually written down). I argue that women's golden garments - such as rings, necklaces, and likely even the fabrics featuring gold embroidery would have been associated with an idealized marital peaceweaving identity. I will examine the ways in which women and their clothing were portrayed in Beowulf and, using mainly the research of Gale R. Owen-Crocker in her book Dress in Anglo-Saxon England, I will establish the connection between the depictions in Beowulf and the contemporary world by looking at the ways in which women and their clothing functioned in early medieval England during the $8^{\text {th }}$ through $11^{\text {th }}$ centuries.

In Beowulf the women are described as covered in gold, and I believe this gold serves as the visual marker of a peaceweaving identity. Queen Wealhtheow is described as "adorned with gold" and "ring-adorned." Another queen, Thryth, is also described as "gold-adorned." Freawaru, the daughter of Wealhtheow, is also described in this exact same way: "goldadorned." The visual marking of the peaceweaver as "gold-adorned" is not confined to Beowulf; it is also shown throughout archaeological materials and other evidence from $8^{\text {th }}-11^{\text {th }}$ century England. Over the course of this time period, women's style of dress changed, with there being a shift in the $10^{\text {th }}$ century from the style of the $7^{\text {th }}$ through $9^{\text {th }}$ centuries. However, the main dress components remained the same, and wealthy women throughout these periods continued to be heavily decorated in jewelry, and in both fashion periods, gold embroidery was popular in luxurious clothing worn by women. Furthermore, according to Owen-Crocker, throughout the $8^{\text {th }}$ 
to $11^{\text {th }}$ centuries, skilled weavers would produce intricate designs in gold and silk and tiny motifs such as animal figures, and this type of gold work was popular and seems to have been a wellknown craft in England.

Some of the most striking features of the $8^{\text {th }}$ century were necklaces and their use of pendants, which were imitations of the Byzantine style. Owen-Crocker writes, "the most sumptuous imitation of the Byzantine style in England took the form of a pendant bullae, usually consisting of garnet carbuncles (occasionally amethyst) set in metal frames, but also utilising other stones and sometimes discs of metal" (144). These pendants could occur alone or in simple arrangements, but also occurred in elaborate groups of necklaces with beads of gold and silver wire. This can be seen in Figure 1, which is a late $7^{\text {th }}$ century necklace from England strung with an alternating pattern of gold and cabochon pendants, gold pendants and biconical gold wire spacer beads (The British Museum). It features a cross in the center that was "curiously constructed of two tubes of heavy gold sheet, cut away where they overlap and lidded at each end" (The British Museum).

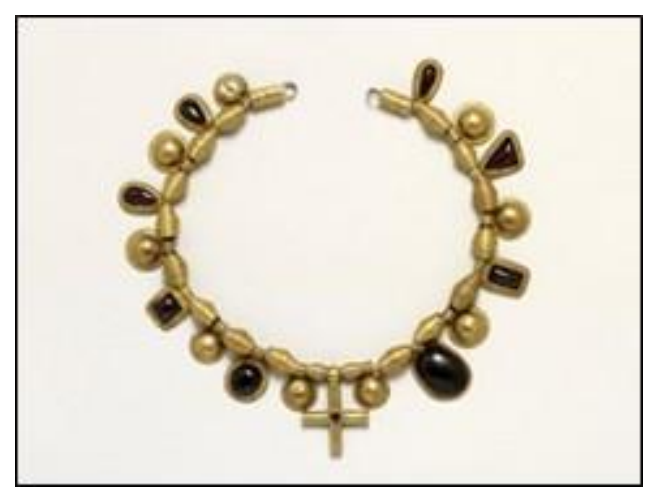

Figure 1. Desborough Necklace. British Museum.

Owen-Crocker discusses an archaeological find of a grave site dated to just before the $8^{\text {th }}$ century in Winchester, England, in which a woman wore at least thirty silver-wire rings, two strung with beads, six assorted bullae and a gold ring, which was fashioned together into a necklace around 
her neck. There is a possibility that these were originally stitched to her garment (145). Other sorts of jewelry were popular as well around this time. Rings, while unpopular in the $8^{\text {th }}$ century, were popular once more in the $9^{\text {th }}$ century (Owen-Crocker 146). An example of this can be seen in Figure 2, a golden ring dated to $9^{\text {th }}$ century England.

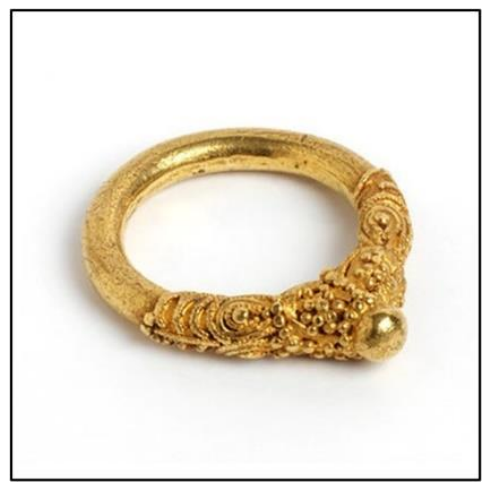

Figure 2. Gold Ring. Victoria and Albert Museum.

Later in the $10^{\text {th }}-11^{\text {th }}$ centuries, gold jewelry such as this continued to be in circulation. Owen-Crocker writes, "it is apparent, both from the wills of laymen/women and from the records of gifts given by seculars to religious foundations, that costly jewelry was certainly in circulation and that this jewelry was probably gold" (207). However, most jewelry from this period has not survived the test of time and has not been found in any excavations. Similarly, in the $10^{\text {th }}$ and $11^{\text {th }}$ centuries other precious garments are evidenced only in writing. Owen-Crocker states that there are documentary sources that indicate that the Normans who came to England were dazzled by the elaborate dress of the women there, and there were recorded textile embroidered with gold not just as an ornament for the edge but "sometimes so heavily decorated with gold as to appear encrusted with it" (228). Artists in this period rarely depicted these opulent fabrics, but rather opted to only suggest elaborate dress by adding an extra layer to the woman's garments, indicated in painted manuscripts by color contrast (Owen-Crocker, 229). This sort of color 
contrast, I believe, can be seen in the woman's clothing in Figure 3, which is an image from the $11^{\text {th }}$ century Bayeux Tapestry.

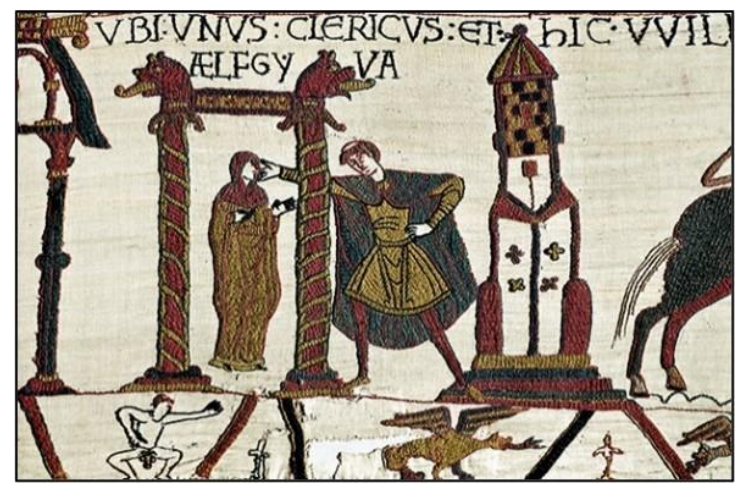

Figure 3. Duke William's daughter Aelfgyve is promised in marriage to King Harold II. Bayeux Tapestry. akg-images.

While the connection between gold clothing and accessories and English noblewomen seems certain, this connection can be narrowed down further to not just noblewomen but more specifically idealized peaceweaving married noblewomen. It is important to first determine what it meant to enact a peaceweaving marital identity for a woman in early medieval English culture. Peaceweaving originates as a broadly Germanic term, as Carol Parrish Jamison discusses in her article "Traffic of Women in Germanic Literature: The Role of the Peace Pledge in Marital Exchanges." Jamison writes that in peace pledge marital exchanges "the woman could become, in the best of situations, a sort of diplomat, participating actively in marital arrangements, advising her husband, and engaging, to some extent, in the negotiations of the mead hall" (14). Essentially, a woman would be married to settle a dispute or rivalry between families. This would likely be done during a time of unstable peace, and she would be expected to stabilize the peace. Once married, the wife would be expected to continue in her efforts to keep the peace between the men of the families by, as Jamison says, serving as a sort of diplomat and advisor. 
In Beowulf, we often see the wives of leaders doing such work in the feast settings, in which she will create and/or strengthen bonds between men as she converses with them and pours their mead. Queen Wealhtheow, King Hrothgar's wife and one of the most prominent women of Beowulf, is a primary example of this custom. She is described as going about to every man young and old, giving each his portion of the precious cup. She speaks to the warrior Beowulf as she does so, using her words of thanks to maneuver the conversation towards eliciting allegiance from him. Later, she is also described as passing rings among men in the hall and urging her young sons to move into action to gain political power and influence. Another queen named Thryth is described as ruling alongside her husband Offa, who becomes widely honored as a result of her partnership with him. The lines are as follows:

Đær hi syððan well in gumstole, gode mære lifgesceafta lifigende breac, hiold heahlufan wið hælepa brego, ealles moncynnes mine gefræge pæs selestan bi sæm tweonum, eormencynnes. Forðam offa wæs geofum 7 guðum, garcene man, wide geweorðod. Wisdome heold eðel sinne. (Beowulf Lines 1954-63)

[There she afterwards in the throne, famous for good, used well her life as ordered by fate while living, held high-love with the ruler of warriors, of all mankind as I have heard say, that of the best between the seas, of the human race. Therefore, Offa became, in gifts and in battles, the bold man, widely honored. He held his homeland in wisdom.]

This set of lines indicates an idealized peaceweaver even more distinctly when Thryth's role as Offa's wife is contrasted with her previous behavior just a few lines earlier. Before finding her place on the throne, "famous for good" she is known to kill any man who dares to look at her, causing great calamity in her father's realm. Her actions - whether to create peace or disrupt it directly impact the outcomes of the community she moves within. Whether she chooses to 
violently cut the bonds between men with the hands of death or weave new bonds of peace between communities is her choice. In Thryth, we see that in the world of Beowulf, the peaceweaving queen was crucial to the politics and success of the community. It only makes sense, then, that a visual marker of this role, such as golden clothing and accessories, would be used to indicate her uniquely vital role within society.

The women described as gold-adorned in Beowulf are usually married, or about to be married. Wealhtheow is married to Hrothgar, Thryth is described as both a bride and wife to Offa, and Freawaru is a bride-to-be. Thryth's description as gold-adorned only appears as she is given to Offa as his bride: "wearð / gyfen goldhroden geongym cempan" [she (Thryth) was given gold-adorned to the young warrior] (Beowulf Lines 1950-51). Similarly, Freawaru is described as "gold-adorned" solely in the following line: "Sio gehaten is, / geong goldhroden, gladum sona Frodan" [She (Freawaru) is promised, young and adorned with gold, to the cheerful son of Froda] (Beowulf Lines 2027-28). She is only described as gold-adorned when it is stated that she is promised to someone as a bride, just like Thryth. Wealhtheow's moments where she is described as gold-adorned, on the other hand, correlate with her doing the expected wifely duties: serving drinks and operating as a diplomat. This can also be seen in the case of Queen Hygd, the wife of King Hygelac, who is said to have her breast be adorned more richly after the ring-giving done by Beowulf (Beowulf Lines 2175-80). These examples suggest that wearing gold was associated with not only noblewomen, but with noblewomen adopting an idealized peaceweaving marital identity.

The connection between gold-adornment and an idealized peaceweaving identity is further supported by later scenes which are notable for women losing their gold adornments after failing to perform this ideal. Later in the poem of Beowulf, the wife of Ongentheow is described as 
"bereft of gold" after her captor, Hæthcyn, is killed and she is rescued by her husband (Beowulf lines 2929-33). In a similar scenario a few pages later, once more, each of the women of Beowulf's community are ordered to never wear a "ring-ornament around her neck" and be "stripped of gold" because their lord, Beowulf, is dead (Beowulf lines 3012b-19). Furthermore, as aforementioned, Thryth is only described as gold-adorned when she is given to Offa as a bride. However, she was described as a peaceweaver before her marriage with him, but when she was unraveling peace rather than weaving it. Her description of gold-adornment comes only when she enacts the role of ideal peaceweaver, rather than its antithesis. Thus, women acting as weavers of peace - through marriage, diplomacy, and action - are described as gold-adorned, treasure-like, but women who fail to weave the bonds of peace, who neglect to prevent conflict, lose that visual signifier, whether or not they were directly at fault for the violence at hand. Once the peace is broken, although the peaceweaver remains a noblewoman, she loses her gold.

The connection between idealized marital peaceweaving and gold is further supported by the contextual usage of the language of peaceweaving. In her article "Formulaic Fripuwebban: Reexamining Peace-Weaving in the Light of Old English Poetics," Megan Cavell examines the word for peaceweaver, fripuwebban, through a formulaic framework and outside of its critical context to make the argument that peaceweaving was much more about status, superiority, and good leadership than about gender alone. Cavell explains that the adjective faele (meaning of people/angels/God or faithful/trusty) often appears in combination with fribuwebba/e in Old English literature. Cavell writes that this formula "indicates that peace-weaving is especially concerned with individuals of elevated status and social or moral importance" (368). An important example that Cavell brings forward is the usage of fale fripuwebbe in the Old English religious poem Andreas. In this poem, Cavell focuses on the following lines: 
He mid Ealhhilde,

Fælre freopuwebban, forman sipe

Hreðcyninges ham gesohte

Eastan of Ongle, Eormanrices,

Wrapes wærlogan (11.5b-9a)

[He with Ealhhild, the faithful peace-weaver, for the first time sought, east from the Angles, the home of the glorious kind, Eormanric, the cruel oath-breaker. Trans: Cavell]

In these lines, according to Cavell, the description of Ealhhild contrasts with that of Eormanric not only in the description of Ealhhild creating peace and Eormanric breaking it, but in the adjectives describing Ealhhild as faithful and Eormanric as cruel. Cavell writes that "the reference to Eormanric's legal failings highlights the nature of marriage as a secular and religious compact, and further points to Ealhhild's expected diplomatic function as queen" (364). In the context of this chapter, it is interesting that Cavell's argument also supports the association of peaceweaving with a higher status within Christianity.

Considering this conclusion, then, that peaceweaving was associated not only with wealth and nobility, but also with pious virtue, it is not surprising that gold became a signifier of these things, as well, and that it became a pattern for women performing the highly idealized version of peaceweaving were described as wearing it. Helen Conrad O'Briain in her article "Listen to the Woman: Reading Wealhtheow as Stateswoman" points out that the adjective "gold-adorned" is consistently associated with superior character throughout Old English literature:

Each mention of physical ornament here is accompanied by reference to her character: "cynna gemyndig" (mindful of family and courtesy (I suggest the poet wishes both concepts to be acknowledged here), 614b); "frēolic wīf" (excellent woman, 615a); "mode gepungen" (with a well conditioned mind, 624a); "frēolicu folcwen" (excellent queen of the people, 641a). Goldhroden is associated with frēolic. (O’Briain 199)

The connection becomes richer when O'Briain explains that the word frēolic is also used to describe Eve, Cain's wife, and Hagar in Genesis and is used in its superlative form to describe Mary in Christ. Once again, we see the connection between peaceweaver (Wealhtheow) and 
Christianity (multiple biblical figures). Not only that, but the connection is further drawn through the added descriptive layer of goldhroden.

The connection between gold-adorned peaceweavers and Christian faithfulness can be further supported when we look at the connection between weaving, textile, treasure, and value in the Old English poetic tradition. Cavell writes that in Exeter Book Riddles 35 and 56, The Leiden Riddle, Beowulf, and Christ III, "we see weaving terminology in the context of treasures, weapons and armour, tapestries, and temple veils. These examples, as well as the other metaphorical uses to which weaving terminology is applied, that is, glory, creation, fate, and language, tell us that woven objects were highly valued in Old English poetry, acting as they do as evidence for human skill” (362). The association of certain ideas and characters with the intricate golden textiles and garments of the period seems to be a physical way of representing the cultural value of what is being associated with it. Describing these peaceweavers as goldhroden or beaghroden serves as a powerful adjective, a material description of them as not only faithful (faele) or excellent (frēolic), but as complex, skilled, and respected peacemakers. Their clothing stands in for the complex language that would be needed to describe who they are and just how important they are in the society of early medieval England.

It is necessary to further examine the reasoning behind the adoption of gold specifically as a visual/material marker of an idealized peaceweaving marital identity. It seems likely to be an attempt to create an association between the women who hold this identity and treasure, which would be highly symbolic because of the way treasure functioned in the society of early medieval England. As Cavell explains, treasure was associated with glory, fate, and served as evidence of human skill. Beyond its symbolic value, Fee explains that in early medieval England, treasure plays a central role in the act of "ring-giving," a process which was the 
primary agent of cohesion in the bonds between thanes and lords, and thus played a vital role in the politics of the period. Fee writes that "in a very real way, a gift from a lord to a thane is a tactile reminder of the loyalty owed to the lord" (289). Erin Mullally further discusses the importance of gift-exchange in early medieval England in her article "The Cross-Gendered Gift: Weaponry in the Old English Judith.” In a gift-exchange, Mullally explains, there are threestrands: an obligation to give, an obligation to receive, and an obligation to reciprocate. She explains the difference between gift-exchange and commerce, explaining that while commerce is primarily economic, gift-exchange is primarily social, with the debt or obligation (always connected to honor, social prestige, and status) unable to be erased until an object has been given in return. Treasure, then, was not valuable just for the wealth of it, but also for the social cohesion it provided.

Thus, as women are visually marked as treasure, they are also associated with the peacemaking role of treasure. Furthermore, Mullally explains that within early medieval English culture, marriage was a form of gift-exchange, with the woman being the gift-object. She writes:

For women characters in Old English texts, ownership of goods is complicated by the more common concept that women are themselves owned. This is not a modern critical view, but one explicit in the literature. Recall the gnomic line, "Cyning sceal mid ceape cwene gebicgan" ("a king shall buy a queen with goods"). As purchased, these women are not viewed as subjects. (Mullally 259)

While I believe it is true that women were considered a gift to be exchanged through marriage, I do not concur that these women were not viewed as subjects. Or, at least, that these women did not view themselves as subjects within this marriage exchange. In her chapter "Voices From the Margins: Women and Textual Enclosure in Beowulf," Leslie Horner describes the main acts of peaceweaving - childbirth and diplomacy - as creative acts, arguing that "the peace-weaver 
produces a 'text' that rewrites history, either her own or that of the two tribes" (69). There is free-will in the production of these "texts," the peaceweaver herself can choose what to "write."

This can be seen in the case of Thryth, who was both a weaver of conflict and of peace. Her choice to do either is what is emphasized when Hygd contemplates her story. Hygd (and by extension, the poet), in her reflection of Thryth, is recognizing that she, and all peaceweavers, can choose to rewrite history in whatever way they, as subjects, choose fit. This can be seen in how Thryth is described as a peaceweaver both before and after her marriage to Offa - both when she is weaving a story of violence and a story of peace. Before her marriage to Offa, before becoming a gold-adorned gift of peace, Thryth is assigned her role of peaceweaver, but rejects it, demonstrating just how much damage can be done if the peaceweaver abandons her appointment. For both the treasure object and the peaceweaver, being recognized as the "object" (or subject) that honor, social prestige, and status rely upon signifies a certain cultural significance, and perhaps even power, that they hold.

The assignment (or adoption) of gold-clothing by peaceweaving women solidifies further in the context of the documentary evidence left behind about gift-exchange in early medieval England. In his article "The Economy of Beowulf" to examine the imagined economy of the elite society in Beowulf, Rory Naismith turns to the actual economy of the elite society in early medieval England, examining the charters left behind documenting gift-exchanges among the upper class. Naismith explains that most gifts recorded within charters were gifts of land; however, precious metals were also often recorded. Naismith is particularly interested in the presence of precious metals, as within the economy of Beowulf, "gold is referred to over fifty times in the poem, either alone or as part of a compound. It stands as a metonym for wealth and treasure more widely" (377). Regarding early medieval English charters and related documents, 
Naismith found that charters which specified the metal used for payment included "221 uses of gold, 45 of both gold and silver together, and 237 of silver" (378). Thus, Naismith argues, there is a clear foundation of the gift-giving of gold and silver for elite identity in early medieval England, interwoven with other symbols and ceremonies of heroic culture. Thus, if gift-exchange was markedly associated with gold and silver, particularly gold in a literary context, then the close association of women with these materials serves to bolster the connection between them and their roles as peaceweavers.

This connection between peaceweaving married women and treasure is further strengthened when we look not only at visual and material markers but also at linguistic markers connecting the two. As aforementioned, Fee argues that there is a connection between peaceweavers and treasures within the context of Beowulf through language such as goldhroden (gold-adorned) and beaghroden (ring-adorned). According to Fee, the word goldhroden (gold-adorned) is used to describe both peaceweaving noblewomen and material objects of treasure in the poem. Additionally, beag (ring) and beaghroden (ring-adorned) appear both in descriptions of peaceweaving noblewomen and extensively in gift-giving and treasure-gifting scenes. Fee argues that this overlap in the language used to describe peaceweavers and treasure serves to show that like treasure, women served as physical memories of the conflicts that caused the peaceweaver and gift-giving to be needed in the first place.

As agents of social cohesion in a society filled with violent conflict, peaceweaving women and peacekeeping objects had a difficult job; peace was fragile. In her article "Hospitality, Hostility, and Peacemaking in Beowulf," Fabienne L. Michelet examines the guest-host relationship and the delicate nature of hospitality in early medieval England. According to Michelet, guests to a hall were always considered a risk - they could attack the hosts, or they 
could entangle the host in their feuds and enmities. To define hospitality, Michelet writes that it is "a space that the host temporarily makes available for the stranger — now a guest—-to occupy. [...] It entails both the outsider's exclusion — he is briefly part of the community — and exclusion - he is symbolically fenced in the space made available for him" (33-34). This space for hospitality, Michelet explains, was created to ensure peaceful cohabitation of the host and guest, yet it often acts as a catalyst for revealing the hostility that it was meant to suppress. Peaceweavers and treasure objects act in a similar way, for they are both host and guest in any situation.

Due to their movement by exchange (moving from the hands from one community to another), they belong to both groups. This is both how peaceweaving wives and peacekeeping objects even create a space for peace in the first place - they are mediators between the two groups originally in conflict. However, as Fee argues, this also makes them reminders on either side of the feud that caused the conflict in the first place. In order for peace to hold, both communities have to do the impossible: they have to bring the peacekeeper (whether wife or object) into their community as one of their own, while also remembering where they came from and why, and simultaneously ignoring the pain brought forth from both of those actions. This can be seen again in the case of Thryth - before marrying Offa, she created societal upheaval with bloody conflict within her own community. She was ripping apart any semblance of the webs of peace. The risk of her continuing that behavior was carried forward in her marriage to Offa. Furthermore, considering that the story of Thryth is included in the internal thoughts of Hygd, an idealized peaceweaver destined for failure later in the poem, as she "Mod pryðo wæg" [weighed the pride of Thryth], indicates a recognition that even the most perfect peaceweaving would always be impossible to maintain (Beowulf line 1934). As Michelet says, "a fragile peace is built 
on spatial distribution and willful oblivion" (36). Despite the negative connotations of the inherent failure of peacekeeping, peaceweaving nonetheless remained a necessity in order to maintain social cohesion and uphold the community. Moving back to the example of Thryth, it is clear by the end of the lines that her role as peaceweaving wife was necessary for Offa to become a good king, widely honored and holding his homeland in wisdom (Beowulf Lines 1954-63). Even with the knowledge that the peace would never hold, that the social cohesion provided was fragile, peaceweaving was required. In a world where feuds were forever, moments of temporary peace and victory were cherished. And, like the warriors dressing in battle gear, the gold-adorned peaceweaver was dressed for a battle that was never won, but undertaken nonetheless.

With these examinations in mind, I believe that it can be concluded there was a clear poetic, linguistic, symbolic, material, and cultural connection between peaceweaving women and treasure in early medieval England. Women's golden garments - their rings, necklaces, and intricately embroidered fabrics - served to identify their idealized marital peaceweaving identities. The connection between peaceweaving and gift-giving in the cultural mindset is established, both the exchange of the bride and of the treasure served to create peace between warring men and to keep the bonds of society intact. The indispensable nature of these roles created a need for a distinct identifier for the position women carried as queens, diplomats, and advisors. This could be seen through women's dress throughout the early English period: notably the Byzantine-style golden necklaces of the $8^{\text {th }}$ century, the intricate rings of the $9^{\text {th }}$ century, and the dazzling gold-encrusted fabrics of the $10^{\text {th }}$ and $11^{\text {th }}$ centuries, as well as the gold embroidery used throughout the entire period. While the usage of luxurious dress as a class-marker is not unique to early English society, the language choices used in Beowulf to describe both women and treasure, as pointed out by Fee, indicate that these dress choices were very likely 
conceptualized as being connected to treasure. Furthermore, this symbolism is strengthened when scenes in which women are described as either being gold-adorned or gold-bereft are linked to either their community being engulfed in either the net of peace or the tangle of conflict. Their gold-adornment signaled not just their status as noblewomen or wives, but their function as peacekeepers and peacemakers: the glue that holds everything together, the agents of social cohesion. However temporarily that glue held, it was a necessary aspect of society, and thus came with great power - the power to weave a lord's story of glorious victory or of terrible loss. 


\section{CHAPTER II: TREASURE AS BEING: OBJECT ORIENTED ONTOLOGY AND OLD ENGLISH LITERATURE}

In the previous chapter, I discussed the parallel function of peaceweaving women and treasure objects within Old English literature and culture. In early medieval England, women and treasure played similar roles: they were exchanged between men to form a bond of peace, acting as the agents of social cohesion. The connection between peaceweavers and treasure was established with the material of gold - as evidenced by women's dress and description within the literature. Interestingly, as suggested by the work of Megan Cavell and Helen Conrad O'Briain, peaceweaving and gold-adornment were also associated with elevated status as well as social and moral importance. In particular, associating certain ideas or characters with gold seemed to be a method of communicating the high cultural value of those ideas or people. In the previous chapter, I argued that by wearing gold, women were marked as playing the role of peacemaker, like treasure, which would be considered an honorable and valuable duty, strengthened by the positive attributes associated with golden textiles.

However, I would like to complexify this argument further. In many locations throughout Old English literature, there are areas in which objects have agency. The Exeter Book riddles provide ample space to argue for the audience of Old English texts valuing the agency of objects, which I will discuss through Riddle 60 and "The Husband's Message," as together they demonstrate the vital role objects played as partners to mankind, an important theme in Beowulf. For example, Beowulf describes his armor as a companion and an active agent in the battle with Grendel's mother: "pær me wið laðum licsyrce min / heard hondlocen, helpe gefremede" [there my corselet did help me against hostile ones, hard and hand-locked] (Beowulf lines 549-50). In the context of these depictions of agentive objects, descriptions of peaceweaving women as 
"gold-adorned" may associate them not with inanimate objects, but agentive non-human beings, and not just agentive non-human beings, but powerfully agentive non-human beings.

This exploration will require an objected-oriented philosophy and ontology to be adopted. According to Graham Harman in his article "An Outline of Object-Oriented Philosophy," object-oriented philosophy is "a method of exploring gaps between objects and their components, objects and their appearances, objects and their relations, or objects and their qualities" (193). In other words, objects have an existence beyond the human, and they are not in existence only when humans are using them. Human perception of objects focuses on how objects are related to other things or to ourselves. So, when we think of a hammer, we cannot perceive it outside of its use as a building tool. Christopher Roman takes up this philosophy in his article "Thinking with the Elements: J.R.R. Tolkien's Ecology and Object-Oriented Ontology." He advocates for an adoption of Object-Oriented Ontology, which proposes a nonhierarchical world between objects and a recognition that objects are not just existent in relation to humans. Roman states that humans tend to only recognize those that have human language as conscious, and otherwise we treat them as non-beings. But Object-Oriented Ontology rejects the idea that objects are only relevant in terms of human access to them and posits instead that objects have properties that are inaccessible to humans.

To conceptualize this, we must consider the object in its relationships with other things outside of human relations with and to them. Roman writes, "When we look at or use an object—such as a chair — we may have access to sitting on it, but we do not have access to its relations, to its relationship with the floor, its connection to its joints, or its sense of stitching" (100). This implies that there is a relation to understand between the chair, the floor, the joints, the stitching. From a human perspective, this is hard to conceptualize: an object, like a chair, 
does not have a sense of self, and will not perceive things like a human does. But ObjectOriented Ontology also plays with the idea that objects may be able to hide consciousness, and thus leaves space to analyze those relations. Roman applies this to animals in Tolkien's work, describing a moment in Tolkien's The Fellowship of the Ring in which Tolkien includes a passage about a fox walking through the woods, seeing the hobbit characters sleeping in the woods, and thinking about how strange their presence there was. In this moment, Tolkien suggests the fox has a consciousness, thinking to itself about the oddity of a group of hobbits sleeping under a tree. The hobbits do not realize that they are being thought about or observed by the fox, but the fox is still having conscious thought. Thinking through Object-Oriented Ontology can be incredibly useful for understanding medieval representations of objects.

This can be seen in the description of textual production in Riddle 60 in the Exeter Book. In Riddle 60, which I accessed in The Exeter Book edited by G.P Krapp and E.V.K Dobbie, the language used to describe the making of the rune-stick indicates that the rune-stick is agentive on similar levels as the human creator of the rune-stick. One example of this at the level of language is the use of the word gepydan in the line "eorles ingeponc ond ord somod, pingum gepydan" [the man's mind and the blade point purposely join together] (Riddle 60 lines 13-14). Gepydan is used at the end of the line in addition to the word somod. Somod means together while gepydan means to join or associate; thus meaning "join together." This is important because this implies that the man and the blade are in fact joining the third aspect of runic text, the reed, rather than simply carving into it. This implies that the reed, the blade, and the man, function as a team in the making of runic texts. The creation of the rune-stick is done by the merging of the reed, the blade, and the man; it is not just a superficial process done by man alone. This interpretation is supported by James Paz in his book chapter “The 'thingness' of time in the Old English riddles 
of the Exeter Book and Aldhelm's Latin enigmata," in which he also discusses this line in Riddle 60 , stating that "the human maker thinks both with and through the changing artefact, the thing becoming some other thing. Knife and hand and inner-thought work together, pressing the speaker for a purpose which is also a meeting and a thing (bingum)" (90).

In Riddle 60, any lack of intentional involvement on the part of the materials would have resulted in the inability to form a runic text. The line reads "eorles ingeponc ond ord somod, pingum gepydan" which I have translated as "the man's mind and the blade point purposely join together" (Riddle 60 lines 13-14). The word pingum, or purposely, adds significantly to the understanding of the riddle. I argue that although pingum can be interpreted adverbially, it can also be read as a noun in the instrumental dative case. According to Bruce Mitchell's Old English Syntax, the dative case of nouns could mean a few different things syntactically - one of the possible syntactic options being that it could have an instrumental meaning, which indicates that the noun is the means with which the subject accomplishes an action. Thus, if pingum is interpreted as an instrumental dative, it maintains a force, then, that suggests intent or a necessity for intentional collaboration. Further, even if not interpreted as an instrumental dative, it can be said that all meanings of the dative are activated. The riddle is stating that if the reed, the man, and the blade did not all join together purposely, the action would not be able to be completed, meaning that the carving would not carry the intended message.

Furthering this idea, pingum gebydan, or purposely joined, is supposed to be separate from the rest of the line. While not separated in the manuscript literally, the phrase makes up the on-verse or A-verse and in most modern printed editions of the poem it is marked as a separate line for this reason. This would cause the reader to pause before saying pingum gepydan when reading the poem aloud. Considering that the verbal reproduction of the riddle is important in 
this context, as most readers of these books such as The Exeter Book had to learn to memorize and recite the texts aloud rather than read from a physical copy, this pause before reading bingum gepydan created an emphasis on these words, further stressing that if the man's mind, the blade, and the reed did not join together purposely, there would be no meaning behind the runic text. This idea of all parts (reed, tool, and man) making the conscious choice to come together indicates that early English peoples might have believed that in order for runic text to be successfully made, all parties, including the reed, had to be willing participants.

Throughout Beowulf, we see weapon objects acting as partners to warriors in battle. Helmets are described as having "ferhwearde heold / gupmod grummon" [guarded the lives of the war-minded] (Beowulf lines 305-306), Beowulf reflects on his armor, saying: "pær me wið laðum licsyrce min / heard hondlocen, helpe gefremede" [there my corselet did help me against hostile ones, hard and hand-locked] (Beowulf lines 549-50), and during his fight with Grendel's mother, his war-shirt is described as "seo ðe bancofan beorgan cupe, / pæt him hildegrap hrepre ne mihte / eorres inwitfeng alder gescepðan" [that who could protect his bone-chamber so that neither a war-grip to the heart nor a malicious grasp of an angry one could harm his life] (Beowulf lines 1447-49). Within his fight with Grendel's mother, it also becomes clear that there was a requirement of all parties to be willing participants when a weapon was in use by Beowulf. Going into battle, Beowulf brought with him the sword Hrunting, gifted by Hrothgar's spokesman. When he entered the under-water battle-hall of Grendel's mother, he first attempted to hit her with Hrunting's blade. However, Beowulf discovered "pæt se beadoleoma bitan nolde, / alder scepðan” [that that sword would not bite or attack her life] (Beowulf lines 1525-26). Hrunting decided not to participate: he "would not bite" or "did not wish to bite" (as nolde is a negative form of the verb willan, meaning did not wish, desire, or will) his refusal rendering him 
useless to Beowulf, ultimately leaving Beowulf briefly without defense against Grendel's mother. While this failure of Hrunting might be attributed to the uniquely monstrous and overwhelming power of Grendel's mother, it is in direct contrast to the work of Beowulf's corselet only a few lines later, "pæt gebearh feore, / wið ord 7 wið ecge ingang forstod" [that protected his life, stood against the entrance of point and of edge] (Beowulf lines 1550-51). Despite both of these items (Hrunting and Beowulf's corselet) coming from outside of Grendel's mother's lair, one was able to successfully partner with Beowulf in his fight, whereas the other chose to refuse him, as he did not have any desire to use his biting power in his time of need.

Beowulf's victory comes when he spots another weapon, an ancient sword of giants, who is willing to cut into Grendel's mother's neck. This sword appears in Beowulf's sight after it is declared that God decided to grant Beowulf victory: "pæt wæpna cyst, / buton hit wæs mare ænig mon oðer / to beadulace ætberan meahte, / god 7 geatolic, giganta geweorc" [the best of weapons, except that it was greater than any other man could carry to battle, good and stately, a work of giants] (Beowulf lines 1561-64). Interestingly, here, Beowulf's success in this battle hinged on the chance that he would find a suitable weapon, and the passing whim of God to grant him victory. This odd happenstance brings forth a similar pattern from Riddle 60. In Riddle 60 , there is an emphasis on the idea of things happening naturally rather than artificially. The riddle begins with the following:

Ic wæs be sonde, sæwealle neah, æt merefarope, minum gewunade, frumstapole fæst; fea ænig wæs monna cynnes, pæt minne pær on anaæde eard beheolde (Riddle 60 Lines 1-5)

[I became by sand, near the seashore, from a sea-wave, I remained fixed in my first state; little was there any of mankind that beheld my homeland in its solitude] 
This description of the reed and how it was found evokes a certain ideal of natural destiny. The reed appearing on earth seems to be completely uncontrolled by man, destined by nature. The reed was born by sand and remained there in that empty land for a seemingly long time before man found it. This description of the reed begins with its early life, and it evokes the feeling of a long period of time passing before it was found by man. Like the sword, it was lying in wait, in some wild landscape, until its human partner happened upon it.

As aforementioned, Roman argues that Object-Oriented Ontology rejects the idea that objects are only relevant in terms of human access to them because objects have properties that are inaccessible to humans. Riddle 60 is also rejecting this idea; the reed has its own existence even before its meeting with men. It has a home on a sandy shore, its own land, which very few men can even behold. Similarly, the ancient sword had a life long before Beowulf; it was created by giants, used by giants, and in the unknown time in-between presumably lived its life in the bottom of the mere before Beowulf happens to find it and use it. In both cases, I would argue, there is a framing of object-oriented philosophy as the natural way of looking at things, which can be seen through the connection between the objects' existences and their wild untouched (by humans) landscapes, as well as through their connection temporally as existing before men even came to their resting places. Through the reed giving its consent, it represents nature and a predestined fate, greater and more powerful forces, giving their consent as well. In the case of the sword, we see an association with a fate decided by the Christian God, who grants Beowulf the sight of the sword and, by his will, melts it after he uses it against Grendel and his mother.

Like the rune-stick left behind as evidence of the coming together of reed, man, blade, and destiny to create a message, the ornamented hilt is left as evidence of the coming together of Beowulf, the sword, ancient beings, and God to slay Grendel's mother. Both rune-stick and hilt 
stand as evidence of this meeting of human and non-human, and of the distant past in which both the sword and the reed originated. In the case of Beowulf, this is seen when Hrothgar receives the hilt. Hroðgar maðelode. Hylt sceawode,
ealde lafe; on ðæm wæs or writen
fyrngewinnes, syðpan flod oflsoh,
gifen geotende, giganta cyn. Frecne geferdon; pæt wæs fremde peod ecean Dryhtne. Him pæs endelean purh wæteres wylm Wadend sealde. Swa wæs on ðæm scennum sciran goldes purh runstafas rihte gemearcod, geseted 7 gesæd, hwam pæt sweord geworht, irean cyst ærest wære, wreopenhilt 7 wyrmfah. (Beowulf lines 1689-1700)

[Hrothgar spoke. He examined the hilt, the ancient remnant: on that an origin of ancient strife was written, from the time when the flood, of rushing sea, slew the race of giants. They severely suffered; that nation was alien to the eternal Lord. For that the Ruler gave them a final reward through the surging of water. So, on those sword-guards of bright gold, it was rightly marked with runic-letters, set and said, for who that sword, best of irons, was formerly made, with a twisted hilt and dragon-design.]

The sword-hilt, here, communicates memories to Hrothgar, readable (and some unreadable) memories and messages, just as the rune-stick does after its creation. Importantly, they both directly (whether materially or textually) communicate their stories. However, the case of Hrothgar is interesting; in his chapter "Æschere's head, Grendel's mother and the sword that isn't a sword: Unreadable things in Beowulf," Paz argues that Hrothgar is not actually reading in this instance, he is simply looking at the hilt - not comprehending the letters. Æschere, who Grendel's mother killed, was his runwita and raedbeora, Hrothgar's community reader. Thus, Hrothgar has been forced to solve the riddle of this hilt. And, he does not have the ability to do so: Paz writes, "the runic letters on the hilt tell us for whom that sword was made without actually relating a name. Thus, Hrothgar does not have all the knowledge to make sense of the 
thing and neither do we, the audience" (53). Yet, despite not being able to make out a name, to solve the riddle, Hrothgar is able to understand quite a lot about this artifact: he learns of ancient strife, of a great flood, a rushing sea, and the death of a race of giants. If Hrothgar could not literally read the hilt, then the hilt must have been speaking to him in some other way.

In Old English, one of the words for humans is reordberend or "speech-bearers." This word for humans categorizes them only by their ability to bear speech, thereby opening up the realm of possibilities for what is human in a variety of ways, including that of the ancient swordhilt. This can be seen more directly in "The Husband's Message" of the Exeter Book. In "The Husband's Message," the rune-stick describes itself, saying, "I was cut and sent / away from my home, holding wily / words, carried out on the ocean" (Burton Raffel 2-4). In both of these cases, an object (the rune-stick), is depicted as bearing speech. Similarly, in Riddle 60, there are multiple points where the rune-stick refers to itself as something that carries speech. In the middle of the riddle, the rune-stick states "Lyt ic wende / pæt ic ær oppe sið æfre sceolde / ofer meodubence muðleas sprecan, / wordum wrixlan" [Little did I expect that I before or after should always, mouth-less, speak over the mead-bench, exchanging words] (Riddle 60 lines 7-10). Then, once more, at the end of the riddle the rune-stick states that the mind, the blade, and the reed join together "pæt ic wip pe sceolde / for unc anum twam ærendspræce / abeodan bealdlice, swa hit beorna ma / uncre wordcwidas widdor ne mænden" [so that I (the rune-stick) with you should, for us two alone, boldly announce our message, so it should not be declared more widely in the words of men] (Riddle 60 lines 14-17). In both cases, rune-sticks are clearly depicted as participating in a form of speech. Additionally, considering that in each of the Exeter Book riddles, the riddles are narrated by a non-human object, it is possible to say that all objects in the 
Exeter Book riddles are speech-bearers. Paz takes up this idea in his chapter when he discusses

the riddles. He explains,

Anglo-Saxon riddlers played with the idea that nonhuman sound can enter human language and reshape it. And the scribes who copied these riddles down did so by using the relics of once living creatures: goose feathers, ink horns, oak gall, sheepskins. Even the letters of the alphabet, which formed the syllables and words and sentences of these poems, were described by Aldhelm in Enigma XXX as the elementa, the smallest component and source element of speech, whose very existence depends not upon the human mouth or hand but upon the iron of the metal stylus and feathers of the writing quill: 'Nascimur ex ferro rursus ferro moribundae / Necnon et volucris penna volitantis ad aetheram' [We are born from iron and by iron die, or from the feather of a bird flying through the sky] (3-4). It becomes difficult to determine at which stage 'speech' and 'writing' is clearly human or clearly nonhuman, or at which stage it goes from living to dead. Hence it is not so straightforward as to say that speech originates with the human and 'dies' as soon as it is alienated from the speaker and transferred onto a nonhuman artefact. ("The 'thingness' of time in the Old English riddles of the Exeter Book and Aldhelm's Latin enigmata," 88)

Thus, it could be argued that when using the word reordberend as a term for humans, humans were not the only ones being referenced - but anyone or anything that the writer considered to be a speaker. Then, unlike modern conceptions, "speech-bearer" as a term does not leave out objects, and the stories communicated by the completed rune-stick and ancient sword-hilt are complicated.

Furthermore, in Beowulf, not only are objects depicted as having speech capabilities, but also the ability to feel. One line of Beowulf that demonstrates this is of particular importance: "No he pone giftstol gretan moste / mapðum for Metode, ne his myne wisse" (Beowulf lines 168169). This portion of lines has been widely debated. When I first encountered this line in PresentDay English, it was from R.M. Liuzza's translation of Beowulf, reading as follows: "he saw no need to salute the throne, / he scorned the treasures; he did not know their love" (168-169). Scholars, like Liuzza, who translate the love as being of the treasure, credit their reading to Fred C. Robinson's suggestion in "Why is Grendel's Not Greeting the gifstol a wrcec micel?" and 
Bruce Mitchell and Fred. C Robinson's book Beowulf: An Edition. In the referenced footnote of their book, Mitchell and Robinson write of lines 168-169, “A much-discussed passage. We suggest this translation: 'By no means was he [Grendel] compelled by God to show respect for the throne, that precious thing, nor did he feel love for it"' (54). In Liuzza's translation, it seems he identified the form as a plural accusative while also suppling a new verb and altering the pronoun "his" to fit a plural meaning; whereas Mitchell and Robinson translated mapðum as an accusative singular noun that serves as a synonym following gifstol. While these are both valid and smart translations, I nonetheless had to follow my own understanding of the grammar and literature when choosing how to represent the lines in PDE myself.

Thus, when I translated the line, I departed from this translation. The main place where I depart from the translations of Liuzza, Mitchell, and Robinson is in my interpretation of the word mapðum. According to Clark Hall's A Concise Anglo-Saxon Dictionary Second Edition, the word maрðum can appear in multiple ways. In its nominative/accusative, it can appear as maðm, maðum, maððum, or maрðит. According to the Dictionary of the Old English Corpus, the only form of the nominative/accusative used in Beowulf is maððum or mapðum. In the other instances of maððит or mардит appearing in Beowulf, whether as a standalone word (two instances) ${ }^{1}$ or

\footnotetext{
${ }^{1}$ Pa sceall brond fretan,

æled peccean, nalles eorl wegan

maððum to gemyndum, ne mægð scyne

habban on healse hringweorðunge,

ac sceal, geomormod, golde bereafod,

oft, nalles æne, elland tredan. (Beowulf lines 3016-21)

[Those the fire-brand shall devour, the flame enfold, the warrior not at all to wear the treasure for remembrance, not the bright maiden to have on her neck the ring-adornment, but she shall, sad of mind, bereft of gold, often, not at all once, tread a foreign country]

Đa gyt æghwylcum eorla drihten para pe mid Beowulfe brimleade teah, on pære medubence mapðum gesealde (Beowulf lines 1049-51)

[The lord of warriors still yet to each of those who with Beowulf took the sea-way journey on the mead-bench distributed treasure]
} 
as the second part of a compound word (one instance) ${ }^{2}$, they are in the accusative case. However, in the instance of line 169 , I opted to translate it as nominative, as I knew from the context of the line that there was a third person singular present verb (wisse) without a clear subject. Thus, I translated using mapðum as the subject of the latter end of the line. Therefore, based on both grammar and cultural context, I found that it could read thus: "He was by no means allowed to approach the gift-seat before the Creator, the treasure did not know his love/mind." Either reading is fascinating. The first translation, by Liuzza, implies that treasure can love, and the second translation would imply that treasure can know, and not just anything, but love.

However, mabðum being the subject of the verb wisse is important in terms of thinking about Object-Oriented Ontology. A debate about the usage of Object-Oriented Ontology in poetic contexts such as Beowulf has been brought forth, as poetry is highly stylized, and it can be difficult to tell the difference between poetic personification and agency. Turning to linguistic theories is an excellent option to differentiate between the two. One such theory was brought forth by Charles Fillmore in his seminal publication "The Case for Case" in 1968. In this chapter, Fillmore argued that there are not just surface cases (such as nominative or accusative) but deep cases, which answer questions about who a given noun, such as who did it, who it happened to, and what got changed. He identified deep cases as fitting into categories of agentive, instrumental, dative, factitive, locative, or objective. Importantly for this examination, some of these deep cases were specifically animate, inanimate, or neutral. After his original publication, these deep cases were called semantic or thematic roles, and they became heavily debated.

\footnotetext{
${ }^{2}$ Hyrde ic pæt he ðone healsbeah Hygde gesealde, wrætlicne wundormaððum, ðone pe him Wealhðeo geaf, ðeoðnes dohtor, prio wicg somod swancor 7 sadolbeorht. (Beowulf lines 2175-78)

[I have heard that he gave to Hygd that neck-ring, the ornamented wondrous treasure, that which Wealhtheow gave to him, the daughter of the lord, as well as three horses supple and saddle bright]
} 
Lilia Rissman and Asifa Majid investigated this debate in their article "Thematic Roles: Core Knowledge or Linguistic Construct?" in which they considered whether or not there is evidence for abstraction or universal biases to distinguish between different role categories such as Agent, Patient, Goal, Recipient, and Instrument. Rissman and Majid explain that "role categories have been thought to reveal themselves through a range of linguistic structures, both lexical (e.g., case markers, adpositions) and syntactic (e.g., grammatical functions such as Subject and Object)" (1851). These thematic roles have psychological reality, which Rissman and Majid argue is evidenced by experiments on event and sentence processing by adults and children. Rissman and Majid found in their research that Agent and Patient were universally clearly distinguished, and evidence that this distinction is a core cognitive construct appears with linguistic studies of infants and of deaf children practicing home-signing, in which they make up their own sign-language as a way to communicate. Goal and Recipient were harder to distinguish, and Instrument appeared to be a non-category - instead often being linked to other roles (such as Agent) rather than functioning as its own. In the context of this study, this seems to suggest that there is a much deeper history for only distinguishing between Agent and Patient, and that categorizing an object as an Instrument is a more recent phenomenon. Importantly, the only real distinction today between Instrument and Agent is animacy, as the Instrument is often classified as an inanimate object used by an Agent to complete the action of the verb. Seeing how infrequently speakers made distinctions between those categories, though, perhaps Old English speakers would not have so clearly differentiated between animate and inanimate.

In the case of "mapðum [...] wisse" [the treasure knew] it is also important to look at the verb itself. Beth Levin examines the typology of verbs in her book English Verb Classes and Alternations by looking at what type of subject different verbs typically take. While her book 
focuses on Present-Day English, it still proves useful for categorizing the verbs that appear in the Old English passages in which objects seemingly are agentive. According to Levin's classing, wisse would be a verb of perception, specifically what Levin classifies as a See-verb. Levin writes, "verbs in this subset of the verbs of perception describe the actual perception of some entity. They take the perceiver as subject and what is perceived as direct object" (186). In the case of Beowulf lines 168-169, then, the subject is treasure (mapðum) and the direct object is love or mind (myne). Inherent in this understanding, the subject and Agent of the verb must be a rational and animate being capable of perception. Thus, in this case, an understanding of the treasure (mардит) as agentive is supported not just conceptually and culturally, but also linguistically.

This linguistic examination can be expanded to aforementioned instances of treasure having human-like agency: specifically, the verbs used in lines from Beowulf to describe Hrunting's actions. It is first important to note that swords like Hrunting were considered treasures, as seen by the references to battle objects (like swords and armor) as treasures. In lines 1525-26 in Beowulf, Hrunting is described as refusing to bite or attack Grendel's mother's life. Both the verbs used in this instance indicate an agentive subject. Bitan (to bite) under Levin's classification is a Verb of Contact by Impact, and more specifically a Swat-verb, which is a verb that relates "to moving one entity in order to bring it into contact with another entity, but [does not] necessarily entail that this contact has any effect on the second entity" (151). Interestingly, Levin explains that Swat-verbs do not allow Instrument-subjects - meaning that the subject must be an Agent-subject, indicating, once more, an animate being. This is further cemented in the second verb of the line, scepðan (to attack or hurt). This verb, according to Levin's classifications, is a Verb of Killing, and more specifically a Murder-verb. This type of verb 
describes killing but does not provide information for how the killing came about. Like the Swatverbs, Instrument-subjects are not used for this type of verb, or at least not frequently. Levin writes, "few members of this class of verbs appear to be able to take instrumental phrases headed by the preposition with. Fewer still allow instrumental subjects; their absence might reflect the fact that many of the allowable instruments are merely so-called 'enabling' or 'facilitating' instruments" (231). Levin specifically provides an example of how this does not work for the verb "murder," with the phrase "the dagger murdered Julius Caesar" being an example of how an Instrument-subject does not function properly. However, that is only an issue when one does not recognize the dagger (or in the case of Beowulf, Hrunting) as an animate Agent of the verb.

In many of the instances of objects showing apparent agency, the verbs that they are subjects of do not specifically require an Agent as the subject of the verb. Therefore, a secondary method of determining the difference between poetic personification and true agency needs to be adopted. Thus, I think it is important to closely examine instances of personified objects; if there are actual consequences to that personification, then agency can be determined. For example, in lines 168-169, even though we are given a verb that clearly indicates an agentive subject, we are also told that Grendel could not approach the gift-seat because the treasure did not know his love. This can also be expanded to the case of Hrunting, whose refusal to bite or attack Grendel's mother almost costs Beowulf his life. This can be extended to the other aforementioned examples as well: if helmets and armor had not been active subjects guarding lives of the warminded (Beowulf lines 305-306) or helping against hostile ones (Beowulf lines 549-50), then they could, like Hrunting, send their warriors to a perilous doom. The corselet that Beowulf wore into the fight with Grendel's mother is an excellent example of this, as its success directly contrasts 
Hrunting's failure. It "gebearh feore, / wið ord 7 wið ecge ingang forstod" [protected his life, stood against the entrance of point and of edge] (Beowulf lines 1550-51).

The corselet also brings up another important aspect of agentive objects in Beowulf; much of the poem focuses on relationship building: the trading of treasure to create peace, the marriage of a couple to unite communities, and the bonds between lords and their men. These relationships are not important only for keeping or creating peace - but also for a warrior's success in battle. In Beowulf, it is written that Beowulf borrowed the sword Hrunting and when he did so "cwæð he pone guðwine godne tealde / wigcræftigne" [said he considered that (sword) a good war-friend, strong in battle] (Beowulf lines 1813-14). Here, there is a point made that Beowulf considers the sword a war-friend, a term I would consider similar to a lord's views of his thanes. There are definitely hints of a comitatus bond, or the powerful bond between lords and men, that had existed most strongly in pre-Christian England and is often represented in heroic literature. However, we never see Hrunting consenting to this bond, and later on, Beowulf's declarations of friendship do not motivate him to act on his behalf: Hrunting "bitan nolde," did not wish to bite, even if it meant saving Beowulf's life. Like the process of making a runic text, there needs to be consent on both parties in the Comitatus for the bond to function successfully. In contrast to Hrunting, Beowulf’s corselet, which was a part of that same war-shirt which was "hondum gebroden" [hand-woven], "sid 7 searofah" [large and skillfully decorated], and "seo ðe bancofan beorgan cupe" [that who could protect his bone-chamber], seems to honor his bond with Beowulf (Beowulf lines 1445-47). In that description of his war shirt, it seems likely that the corselet was made specifically for Beowulf and that they had fought in battles together before. Holding that Comitatus bond with his corselet, then, seems to be what motivated Beowulf's armor to continue to protect him against Grendel's mother's attacks in the mere. 
This idea is crucial in the context of this chapter; from this idea, there can be seen patterns of human and non-human object friendship and teamwork in both Beowulf and Riddle 60. Although there is no literal battle in Riddle 60, the Comitatus bond can be seen in the joining together of the man, the reed, and the blade. This reflection can be seen when considering that the Comitatus bond is the pledge to never leave one another's side in battle, but to always stay together and serve one another. The idea of the coming together of the man, the reed, and the blade, to create a runic text is similar to this pledge. While it is not made for purposes of war, it is a sacred and permanent pledge to one another. As long as the rune-stick exists, the reed, the blade, and the man, will be joined. In Beowulf, Beowulf and his corselet literally seem to hold a battle-bond, with his corselet dedicating its utmost willpower to guard Beowulf's life. Thus, when it is indicated that Grendel "was by no means allowed to approach the gift-seat before the Creator, the treasure did not know his love/mind" in lines 168-69, it is incredibly interesting that the treasure and Grendel having some sort of Comitatus-like bond would allow him to approach the gift-seat and have some effect on his fate through the agency of its knowledge. In the Comitatus-bond, the lords' men serve him and respect him, and he serves and respects them; it is a balanced relationship rather than solely one sided. The objects (the rune-stick, the sword, the corselet, and the treasure) hold a mutually dependent bond with mankind, and their agency is necessary to complete the actions that their lord (Beowulf) wants to complete.

However, it becomes clear on further inspection that treasure objects in Beowulf that not only are men reliant upon these agentive objects' to willing participate in the tasks they set out to complete, but also that objects are capable of acting with agency in the world without relying on men to do so. This can be seen at the end of the Beowulf poem in the form of the dragon's hoard of treasure. First, before the dragon's anger is fully discussed, the poet chronicles the treasures 
themselves and their pasts. The treasures are described as being in the earth, evidence of a rich legacy of a noble race who had all been seized by death. The treasures, after the only survivor of this noble race dies, are briefly alone, until the dragon comes and guards the hoard. Unlike in other areas of Beowulf, the treasure here is not serving a purpose to create an alliance or work as a battle-partner. It is simply existing, "eldum swa unnyt swa hyt æror wæs" [to men as useless as it previously was] (Beowulf line 3170), and then creating chaos out of that existence: it attracts a dragon. In this sense, though, it can be understood that the early medieval English poet seemed to be recognizing that the treasure had a purpose outside of men. It was used by men, then left behind upon their deaths. Even when humans were no longer around, the treasure was still there and affected the world, all on its own. In fact, the treasure untouched by man, has perhaps its greatest effect: when it was untouched, the dragon was most attracted to it.

Helen Price discusses the connections between objects, the physical world, and the past in her chapter "The Hoard Uncovered: Objects and the Ground as Poetic Ecosystems." One of her main focuses is the treasure hoard, which she argues maintains a sense of activity and agency while it is within its enclosure. While Price's focus is mainly on the ways in which the ground plays a role in the treasure hoard, many of her arguments are quite relevant for examining the agency of treasure within this chapter. For example, Price explains that in Old English poetry, "the hoarding of treasure is a negative quality, and that hoards exists to be unlocked" (140). She also argues that in Old English poetry, art, and artefact ornamentation, there is a connection between women and earthen or subterraneous enclosures. She writes that "occurrences of this trope include the dwelling place of the speaker in The Wife's Lament, probably the right-hand panel of the Franks Casket, and arguably the cave/underground dwelling of Grendel's mother in Beowulf' (153). And, not only is the ground seen as feminine, but also as an anti-hall, a place 
that "inverts normal characteristics associated with the Anglo-Saxon hall as a place of social order, security, and community" (153). In these arguments, it can be seen that the place where treasure is kept, the treasure hoard, is everything that is opposite of the early medieval English heroic culture. Its power comes from being not only separate, but also the opposite of the masculine warriors of the poem and their community.

Furthermore, it is important to note that, as Price says, the treasure hoard exists to be unlocked. Yet, in Beowulf, I would argue, the hoard is never really unlocked. The unlocking of the hoard happens when it is opened for circulation. The negative aspect of the hoard being locked is that it is "being rendered useless through being removed from circulation" (Price 150). Beowulf, upon entering the hoard, is able to kill the dragon that guards it; however, he also dies within the hoard's enclosure. Furthermore, at the scene of Beowulf's funeral, the treasures are burned along with his body. Like the ancient sword's blade used to kill Grendel's mother, the treasures are devoured by heat and melted away, rendered useless to those who survive Beowulf. In his chapter “Æschere’s head, Grendel’s mother and the sword that isn’t a sword: Unreadable things in Beowulf," Paz writes that "we begin to confront the 'thingness' of an object when it does not behave how it is meant to behave, does not carry out the role it was made and intended for, and suddenly exerts its own power - a power to disrupt human activity, custom or ritual and to assert its own presence" (45). Both when the treasure hoard is first introduced to the poem and when it is extracted from the poem, it forces us to confront its chaotic agency, as it is not doing what it is expected to do, and it is acting outside of man.

Even as Beowulf fights the dragon, it is not doing what it is expected to do. Beowulf's men abandon him, all except one, despite the motivation of treasure supposedly being one of the 
binding agents of the Comitatus bond. Wiglaf, the only warrior to stay with Beowulf in his final battle, reminds the warriors who did not accompany them of this:

Pæt, la, mæg secgan se ðe wyle soð specan, pæt se mondryhten, se eow ða maðmes geaf, eoredgeatwe, pe ge pær on standað, ponne he on ealubence oftgesealde healsittendum, helm 7 byrnan, peoden his pegnum swylce he prydlicost ower feor oððe neah findan meahte, pæt he genunga guðgewædu wraðe forwurpe, ða hyne wig beget. Nealles folccyning fyrdgesteallum gylpan porfte (Beowulf lines 2865-75)

[That, (indeed!), who wishes to tell the truth can say that the lord of men, that gave you all these treasures, military-ornaments, that you all stand in there, when he often on the ale-bench gave many a helmet and corselet to hall-sitters, a lord to his thanes, as he, most powerful, could find anywhere, far or near, that he completely and angrily threw away war-gears, when battle befell him. The folk-king needed not at all to boast of warcomrades!]

In reminding them of the loyalty they should have performed for their lord Beowulf, Wiglaf immediately turns to the treasures they were gifted, reminding them that even before him now, they continue to wear those pledged signs of love. Like the creation of the rune-stick in Riddle 60 , like the use of swords in Beowulf's battles, for treasure to work as a bonding agent, all parties need to be consenting. In this case, it is ambiguous who is at fault - the treasure or the men - but whatever the case, both failed Beowulf in the end.

From the perspective of a masculine heroic figure like Beowulf, this failure is negative. However, from the object's perspective, it is evidence of the power they hold through their agency. Like men, they can choose when to honor their bonds and when to abandon them and they can choose what pledges they do or do not make. And, critically, they are influenced by feelings of love (as identified in Beowulf lines 168-169) that are similar to the bonds of love felt by men. And, as it is for men, this love can be fickle. Ingeld, the son of Froda, is described as 
having woman-love that cools after agitating memories of a past conflict: "Syððan Ingelde / weallað wælniðas and him wiflifan / æfter cearwælmum colran weorðað” [Afterwards the deadly enemies of Ingeld surge and love for a woman becomes cool to him after the agitations] (Beowulf Lines 2067-2069). Just as those of Ingeld, the feelings a treasure or weapon has for a man can cool, and when that happens alliances, battles, and lives are at stake.

By looking at these examples within Beowulf and parallel agentive objects in Exeter Book Riddle 60 and "The Husband's Message," it can be determined that in these contexts objects could be recognized as agentive, and more specifically for this study, treasure objects were recognized as agentive. As_Roman explains, Object-Oriented Ontology advocates for the idea that objects have properties that are inaccessible to humans, have consciousness that they can hide, and can use their consciousness to alter the world around them. Adding that it seems objects in early medieval England were depicted as being able to speak, as well, makes it so that there is very little difference in an object's ability as compared to a human's ability. This is supported by linguistic examinations of semantic roles and Beth Levin's typology of English verbs. In critical instances of objects having agency, they are subjects of verbs that will only take a rational and animate Agent as their subject. This could be seen in the cases of Hrunting's refusal to bite or attack Grendel's mother (Beowulf lines 1525-26) and treasure being the subject of the verb "to know" (Beowulf lines 168-69). Furthermore, in instances where the semantics were less clear, the agency of the objects was indicated by the important effects their agency had. If they did not complete the action of the verb as active subjects, then the action would not be completed, and the man involved (like Beowulf with Hrunting) would fail at his task. And, like humans, objects can act alone - there is no requirement for them to be in use by man in order to 
exercise their agency. The treasure-hoard, as the opposite of the masculine, the antithesis to heroic society, was most powerful when alone. 


\section{CHAPTER III: WHEN PEACEKEEPING FAILS: EXPRESSIONS OF ANXIETY OVER POWERFUL OBJECTS AND POWERFUL WOMEN}

In the last chapter, I argued that masculine warriors like Beowulf relied upon the consensual partnership with weapons, armor, and other treasures, in order to be successful in battle and to be successful as lords. In the battle with Grendel's mother, this need for consent in partnership can be seen in Beowulf's use of Hrunting and his corselet. Hrunting does not wish to bite (bitan nolde) Grendel's mother (Beowulf lines 1525-26), and so he does not, despite Beowulf's dire need for Hrunting to do so. This unsuccessful partnership is in direct contrast to the collaboration of Beowulf's corselet, who "gebearh feore / wið ord 7 wið ecge ingang forstod" [protected his life, stood against the entrance of point and edge] (Beowulf lines 1550-51). This consent seems to do largely with the representation of attitudes on the part of the object towards the human and vice versa. Hrunting is a borrowed weapon, and while Beowulf expresses that he considers Hrunting a friend, there is never any indication of reciprocity; Hrunting is described in terms of what he will not do, but never as a willing partner or friend to Beowulf. Furthermore, Hrunting is borrowed from Unferth, a warrior who seemingly disapproves of Beowulf and describes the swimming match with Breca as risking his life over a "foolish boast" (Beowulf lines 507-28). Hrunting, then, is connected to a somewhat antagonistic figure for Beowulf. In comparison, Beowulf's corselet was specifically made for him, they had a history of being in battles together. Perhaps this difference in relationship is why Hrunting does not wish to bite whereas Beowulf's corselet protects his life. However, the relationship between man and object is not the only factor to determine the object's participation in the man's goals. In the treasurehoard, we see that objects can be powerful when they are on their own, independent of their use to men. In man's absence, the treasure-hoard attracts the dragon. Furthermore, the treasure- 
hoard, from the perspective of men, is meant to be unlocked, yet Beowulf is unable to do so, receiving a fatal poisonous wound within that hoard's walls: his dying wish is to be able to see within that hoard once more. It does not do what is expected - which is to be unlocked and taken by man. Similarly, the treasures Beowulf distributed to his men also fail to motivate them to protect his life in this final battle. This failure is negative in the eyes of the warrior, Beowulf, but would it be negative from the perspective of the objects?

Already, we have seen instances in which the agentive object is not on equal footing with mankind, but a step above, instances, for example, in which Beowulf believes he has control over an object and then find outs he has absolutely no control over it. Even though Beowulf pledges himself verbally to Hrunting, saying he will consider the sword a war-friend and thus initiating a Comitatus pledge (Beowulf lines 1813-14), Hrunting fails him by refusing to bite Grendel's mother. In this supposedly mutually dependent pledge, Hrunting holds Beowulf's life in its hands. The feelings of anxiety that this incident caused in Beowulf are seemingly expressed when he is left weaponless, "Strenge getruwode, / mundgripe mægenes. Swa sceal man don, / ponne he æt guðe gegan penceð / longsumne lof" [He trusted his strength, his hand-grip of might. Like a man should do, when he intended to win long-lasting praise in battle] (Beowulf lines 1535-38). In that very moment, the Beowulf poet steps into the narrative to express anxiety about man's reliance on objects. Just as Beowulf realizes he must rely on his strength instead of Hrunting, the poet communicates that a man cannot (and should not) trust his weapons, as they can and will break the Comitatus bond between themselves and their warriors (or never even consent to the bond in the first place); a good warrior knows that he must rely on only himself in battle. 
This theme of distrusting his weapons returns once more for Beowulf when he goes to fight his final battle against the dragon. He says, "Nolde ic sweord beran / wæpen to wyrme, gif ic wiste hu / wið ðam aglæcan ells meahte / gylpe wiðgripan, swa ic gio wið Grendle dyde" [I would not wish to bear a sword, a weapon to the dragon, if I knew how else I could grapple with that combatant, with pride, as I once did against Grendel] (Beowulf lines 2519-22). Like Hrunting, his sword once more fails him, the failure being ruminated on twice in repetition: "pæt sio ecg gewac, / brun on bane, bat unswiðor / ponne his ðiocyning pearfe hæfde / bysigum gebæded" [that edge failed, shining on bone, bit less strongly than his people's king had needed, constrained in toils] ... "guðbill geswac, / nacod æt niðe, swa hyt no sceolde, / iren ærgod" [the war-sword failed, naked in battle, as it never should, once-good iron] (Beowulf lines 2578-81 and 2585-87). This pattern of Beowulf's weapons failing him is not limited to his battles with Grendel's mother and the dragon. In fact, the Beowulf poet explains: "him pæt gifeðe ne wæs, / pæt him irenna ecge mihton, / helpan æt hilde. Wæs sio hond to strong, / se ðe meca gehwane mine gefræge / swenge ofersohte" [It was not granted by fate to him that edges of irons might help him at battle. That hand was too strong, he who, as I have heard told, each of his blades overtaxed with his blow] (Beowulf lines 2683-87). After a consistent pattern of overburdening his weapons, it would make sense that Beowulf felt ill at ease with the power these weapons, these treasures, held over his life. He longed for a time when the only strength he needed to rely on was his own and he did not have to rely on objects he could not trust and could not control.

Even objects that do not fail Beowulf can become a focus for concern about the agency of objects within the poem. The sword that aids Beowulf in the fight with Grendel's mother, for example, that powerful sword of giants, the God-sent key to victory, just as quickly vanished as it was seen and used by Beowulf. The remaining hilt, despite being a treasure in and of itself, is 
mainly brought back by Beowulf to serve as the only evidence of his victory against Grendel's mother. It has the power of communication, and it tells of its distant past-life, that of giants, and of its creator. Yet, this power of communication, which is what is needed to demonstrate Beowulf's victory, is exactly what makes the hilt so threatening. In his first chapter “Æschere’s head, Grendel's mother and the sword that isn't a sword: Unreadable things in Beowulf,' Paz discusses the unreadability of the sword-hilt and its connections to the uncontrollable power of Grendel's mother, God, and the unknown. He writes, "the hilt embodies a concern over how stories of the present are conveyed to future audiences and, specifically, how histories may be transformed by kinds of artefacts that carry them. Unreadable things can disrupt a longstanding human reliance upon legibility, altering the way we interpret that which has come before us" (Paz 35). This concern can be seen by the way Hrothgar attempts to read the hilt when Beowulf presents it to him.

Firstly, Paz points out that Grendel’s mother specifically killed Æschere, the designated reader of Hrothgar's hall, thus forcing Hrothgar to perform that role in his absence. Furthermore, importantly, Hrothgar cannot fully read the hilt. Paz explains:

Hrothgar's verbal response to the rune-marked hilt demonstrates not only that he cannot readily interpret what he sees there, but also that he does perceive the power of the thing he holds in his hand. The runic letters on the hilt tell us for whom that sword was made without actually relating a name. Thus Hrothgar does not have all the knowledge he needs to make sense of the thing and neither do we, the audience. (53)

Thus, Paz argues, while Hrothgar has the ability to look at the hilt's surface, he cannot penetrate it. What is communicated to Hrothgar then is "the very impenetrability, the otherness, of the thing he is gazing upon" (Paz 54). Instead of seeing Beowulf's glorious victory over Grendel's mother, Hrothgar reads the sword, and by extension Beowulf, as alien and threatening, similar to the giants who created it. Once again, we see an object that Beowulf bonded with acting outside 
of the use Beowulf intended for it; instead of acting as evidence that brings him pure glory and praise, the sword-hilt leaves Beowulf on the receiving end of a warning from Hrothgar as he speaks of the bad king Heremod. Paz writes, "Having examined the hilt and seen an alien history that he cannot rightly read or resolve, Hrothgar is warning Beowulf against becoming monstrous to future generations who will read his story" (55). Just as the sword, that "giganta geweorc" [work of giants] (Beowulf line 1564), became monstrous to Hrothgar as he read it, Beowulf, too, became monstrous in his reading.

But what about the hilt made it so threatening to Hrothgar? In "The 'thingness' of time in the Old English riddles of the Exeter Book and Aldhelm's Latin enigmata," Paz discusses stone as a material. He writes, “stone's power was bound up with its ability to endure across multiple human lifespans, to outlive the men and women who shaped it into a monument or fortress and to carry the power of the past into the present, its stony life vaster than empires, and more slow" (73). This hilt's very existence is evidence of its longevity. As Hrothgar gazes at it, he reads that this hilt existed long before man, before language recognizable to Hrothgar could be carved into it, and he understood that this hilt would likely outlast himself. The reading of impenetrable otherness then perhaps comes from the recognition that the past will long outlast the present, the material (literal and metaphorical) it is made out of is durable and stable, whereas the contemporary is always changing, always moving, and always threatened with being lost to the past. The hilt is a reminder that the past has power that the present will never seem to hold, and similarly, objects that can exist across the past, present, and future, will have a power that mankind will never possess.

This reminder also comes in the form of the dragon's hoard of treasure. As discussed in the previous chapter, this hoard of treasure was left behind by some past noble race, all dead, and 
then the hoard attracted a dragon in the absence of mankind. When it was untouched by man, on its own, is when it had its greatest effect. Like the stone Paz discusses, the treasure here has power in that it can endure across multiple human lifespans, but also that in its endurance it can cause havoc. Furthermore, as explained in the previous chapter through Helen Price's "The Hoard Uncovered: Objects and the Ground as Poetic Ecosystems," the treasure hoard exists to be unlocked, yet, in Beowulf, it never truly is. Beowulf is able to kill the dragon, but dies within the bounds of the hoard, and the treasure is burned along with his body at his funeral. This burning happens despite Beowulf telling Wiglaf, in his dying speech, "Nu ic on maðma hord minne bebohte / frode feorhlege. Fremmað gena / leoda pearfe. Ne mæg ic her leng wesan” [Now I continuously have exchanged my hoard of treasures with an old and wise life. They will be of further use to the need of the people. I cannot be here long.] (Beowulf lines 2800-02) $)^{3}$. Wiglaf is the one who clearly disobeys him in this dying wish, burning the treasures to essentially punish the people who let Beowulf die, but I would argue that throughout the poem treasures, too, disobey him. The weapons he has used throughout have almost all betrayed him in some way. And, furthermore, just about thirty lines before Beowulf's request to Wiglaf, we are told "Sinc eaðe mæg, / gold on grunde, gumcynnes gehwone / oferhigian ${ }^{4}$, hyde se ðe wylle" [Treasure can easily, gold in the ground, overpower each of mankind, hide that who wishes] (Beowulf lines

\footnotetext{
${ }^{3}$ In this passage, I translate fremmað as "they will be of use." This translation aligns with R.M. Liuzza's translation of the word in his translation of Beowulf. While fremmað has often been translated as an imperative singular addressing Wiglaf, as Liuzza explains in his own footnote, "the OE verb may be indicative or imperative, but it is unambiguously plural, and the imperative plural is not used elsewhere in the poem to address a single person" (133). Furthermore, given the context of the surrounding speech of Beowulf (in which he heavily focuses on the treasures), it makes more sense for Beowulf to be saying that the treasures will give help to the people in his absence. ${ }^{4}$ In Clark Hall's A Concise Anglo-Saxon Dictionary, oferhigian is defined as "to delude" or "to turn the head of." R.M. Liuzza translates the verb in the spirit of such a meaning: "give the slip..." Liuzza also notes that the verb could be translated as "get the better of..." This meaning seemingly stems from higian meaning "to hasten, hie, or strive" (Bosworth Toller's Anglo-Saxon Dictionary Online). Kevin Kiernan provides all these meanings of oferhigian: "to overcome, to overpower, to delude, or to be overcome by deceit" (Electronic Beowulf 4.0). Given the meaning of higian, I opted to translate as "overpower," but any of these translations is nonetheless interesting in the context of this study.
} 
2765-67). Even as Beowulf believes he has conquered the treasures, collecting the hoard for his people, they still oferhigian [overpower] him, and the hoard stays unlocked and undistributed. Maybe, this is like Exeter Book Riddle 60, in which all parties (in this case, Beowulf, Wiglaf, and the treasures), must consent to their use, or else the intended action is skewed and ultimately lost. This, as aforementioned in the last chapter, was also the case with the treasure Beowulf distributed to his men to solidify their pledges of loyalty, the Comitatus bonds he held with them. As Wiglaf says in his speech to them (Beowulf lines 2865-75), those treasures did not motivate them to stand by his side in his final battle with the dragon, even though Beowulf gave them out freely and frequently. Treasures in Beowulf have the power to unite men, to win battles, but they also have the power to overcome the men who seek to use them. This overpowering would be seen as negative by the masculine heroic figure such as Beowulf or Wiglaf, but when viewed from an object-oriented perspective, it is not quite so; the treasure is simply powerful, wherever that power is directed.

This power becomes very interesting when examining Price's argument that there is a connection between women and earthen or subterraneous enclosures. The ground, Price says, is seen as a feminine space as well as an anti-hall, a place that "inverts normal characteristics associated with the Anglo-Saxon hall as a place of social order, security, and community" (153). The place where treasure is kept, the treasure hoard, is everything that is opposite of the early medieval English heroic culture, and those qualities seem to be what make the treasure hoard so desirable, so powerful, and so threatening. Treasure's unpredictable, uncontrollable, and powerful nature is associated with the feminine. And, vice versa, peaceweaving women, especially in Beowulf, were associated with treasure: unpredictable, uncontrollable, powerful treasure. Both seemingly have a duplicity: they are expressly needed for society, for men, to 
function, but they are also extremely threatening to the functioning of that society, of those men. Perhaps, then, peacemaking treasure and peaceweaving wives were not just recognized for their ability to provide social cohesion, but also for their ability to unravel the bonds of peace they were expected to make. In their unreadability, their inaccessibility, these objects and these women hide their thoughts and feelings, and they can choose whether to help or to hinder the success of the men that rely on them.

Discomfort is invoked when both peacemaking objects and peaceweaving women act outside of their expected roles. As Paz writes, "we begin to confront the 'thingness' of an object when it does not behave how it is meant to behave, does not carry out the role it was made and intended for, and suddenly exerts its own power — a power to disrupt human activity, custom or ritual and to assert its own presence" (“Æschere's head, Grendel's mother and the sword that isn't a sword: Unreadable things in Beowulf' 45). This applies to peaceweaving women, as well. As Shari Horner explains in her chapter "Voices From the Margins: Women and Textual Enclosure in Beowulf," when the peaceweaver stops doing what she is expected to do, such as when Wealhtheow reprimands Hrothgar (Beowulf lines 1169-80) for seemingly caring more for Beowulf than his own son, she disrupts activity of the community, particularly the masculine community. Horner writes:

Her transformation from a silent cupbearer to a commanding speaking presence is a rewriting of the peace-weaver's role and a disruption of it as well. By reprimanding Hrothgar and abandoning the ceremonial tasks of the peace-weaver, Wealhtheow unsettles (unweaves) the relationship he is attempting to build with Beowulf, even as she works to bind Hrothgar more closely to his own kin. (78)

This disruption is multiplied in those who I would term nightmarish peaceweavers in Beowulf, namely, Thryth and Grendel's mother. Horner calls these two "exemplars of the dangers of uncontrolled feminine power" (79). 
While Grendel's mother, unlike Thryth, is not identified as a peaceweaver, I would argue she exists as a sort of nightmarish peaceweaver. Beowulf comes to her underwater hall as a guest, whom she hosts, although in a much different way than an idealized peaceweaver would. Like the treasures that bring Beowulf so much anxiety, she is uncontrollable. Horner discusses this in her chapter, explaining, "her namelessness defines her place in the poem's symbolic order: if naming one's enemies is a form of controlling them, this particular enemy is initially beyond control" (82). Horner argues that Grendel's mother's uncontrollability comes from her remaining "outside of the peace-weaving economy of exchange, and thus outside of any kind of physical or cultural enclosure" (82). However, I would argue her threat, her uncontrollability, comes from her being far too capable of functioning within this economy of exchange, both as a feminine peaceweaver and a masculine warrior. As a peaceweaver, she can identify which man is most important to Hrothgar, the head of the community responsible for her son's death; she knows exactly who to kill to hurt both Hrothgar and the community most. As a warrior, she performs the masculine act of revenge by killing that retainer. As a monster, she represents the fear of what could happen if peaceweavers escaped the confines of peaceweaving; much like the treasure-hoard, there is a fear that the peaceweaver might find she is more powerful outside of the realm of men.

The story of Thryth functions to control this threatening possibility. She begins her story as a disruptive peaceweaver and ends it as an idealized one. Before performing her expected roles as peaceweaving wife, Thryth is described as pridefully committing "leodbealewa" [great afflictions] and "inwitniða" [hostile acts] to men of her community (Beowulf lines 1949-1950). Megan Cavell discusses Thryth's beginnings in her article "Formulaic Fribuwebban: Reexamining Peace-Weaving in the Light of Old English Poetics," writing: 
Since a peace-weaver is someone who acts toward the construction of peace through diplomacy, we can assume that the poet is commenting that while [Thryth] should be constructive, she is constrictive instead. As a woman whose status places her in the ideal position to become a diplomat, [Thryth's] resistance to the taking on of this role and her actions, which directly contradict the role, are criticized. (370)

The outright criticism of her actions, followed by praise for her reformed behavior after marriage, all within the context of Hygd (a peaceweaving wife) reflecting on Thryth's story, seems to be an attempt to communicate that the peaceweaver herself would be happier if she just performed her role as expected within this masculine economy. The peaceweaving wife could, like Thryth, begin performing her duties and become "gode mære" [famous for good] (Beowulf line 1955), or she could suffer the fate of Grendel's mother: death.

In Thryth, as well as other gold-adorned peaceweavers, an attempt to control, or at least appear to control, treasure can be read. As aforementioned in chapter one, Thryth is only described as gold-adorned when she becomes a bride to Offa: "wearð / gyfen goldhroden geongym cempan" [she (Thryth) was given gold-adorned to the young warrior] (Beowulf Lines 1950-51). Furthermore, when other peaceweaving women failed to keep the peace, they lost their gold-adornments. This is the case for the wife of Ongentheow, who is bereft of her gold after being captured by Hæthcyn as well as for the women of Beowulf's community after his death. Both peaceweavers and treasure were needed for the social cohesion they provided: men relied upon them for their success, whether in the hall or at battle. If a peaceweaver was not performing her expected duties, and, like Thryth and Grendel's mother, decided to weave webs of violence, while also partnered with the uncontrollable power of treasure, then that would be far too threatening to the masculine economy. In the context of Beowulf, in order for the threat to be contained, the two could not be linked too closely. Otherwise, she may harness the power over men that Thryth holds, while also existing outside of the masculine economy as Grendel's 
mother does, thus making the power relegated to leading men defunct. If a woman were to be gold-adorned, treasure-like, she must be performing her expected duties - she must be actively maintaining the bonds of peace.

In another context, though, this threat can be examined. The binding of Judith and Beowulf together within the Nowell Codex appears purposeful; these poems address many similar issues, with anxieties about the power peaceweavers and treasure being one such issue. In Judith, issues are brought forth about the masculine economy, about womanhood, and about treasure, all within a biblical context. The poem is incomplete in the Nowell Codex and only begins at a large feast held by Holofernes, the leader of the invading army to Judith's community. Judith enters the camp before this feast voluntarily, offering herself to Holofernes in order to kill him and bring her people victory. Holofernes does not know this, and decides to hold a celebratory feast, much like an early medieval English lord would be expected to do for his retainers. He and all of his men, upon his orders, become extremely drunk. After the feast with his retainers, they bring him and Judith to his bed, where he passes out. As he lies drunk, Judith takes his sword and, in two strikes, cuts his head free. With her maidservant, she puts it in her food bag and travels back to her community, showing the head as a sign of victory. In the morning, Judith's army attacks the Assyrian troops on her command, and the Assyrian troops lose upon finding that their leader is dead in his bed. Afterwards, Judith is brought the treasures of Holofernes, which she accepts while crediting God for her victory and looking forward to the continued rewards of heaven that await her.

Key differences between the Judith found in Nowell Codex and the Judith in the Latin Vulgate emphasize the importance in the poem of issues surrounding peaceweavers, treasure, and masculinity. In the Latin Vulgate version, Holofernes does not hold a feast, commanding all 
of his men to get drunk. He drinks and feasts with Judith alone in his tent until he is inebriated. Additionally, in the Latin Vulgate, Judith is referred to as a widow repeatedly and often praised for her dutiful honoring of her late husband. In the Nowell Codex, Judith's widowhood is never a point of focus. There is a possibility that perhaps this was more of a focus in the parts of Judith that were lost, but, given that her widowhood was a consistent feature in the Vulgate, I would argue it as an important point to differentiate. Another key difference is that the curtain around Holofernes' bed is heavily focused on in the Old English poem; in the Latin, the curtain is mentioned, but in the Old English, it is described in detail as a golden net that can only be seen out of, not into. And, finally, one of the most important differences for this study, in the Latin Vulgate, Judith refuses the treasures brought to her and instead offers them up to God.

In changing the context of the feast, the poet seems to be centering concerns around the early medieval English hall, and thus the masculine warrior culture. This is also supported by the focus on the curtain around Holofernes' bed (Judith lines 50-53), which seemed to be focused on for its violation of the trust of the Comitatus bond. Holofernes could see out of it, but his men could not see into it, indicating a very inequal relationship between lord and retainer. Karma Lochrie discusses this relationship in her article "Sexual Violence and the Politics of War in Old English Judith," explaining that with this net around his bed, Holofernes is exercising his power by means of the masculine gaze. This gaze, Lochrie explains, is one of a voyeur who desires sadistic power that forces the object of the gaze to be cast as a passive, masochistic, feminine victim. With his net, Lochrie argues, "Holofernes is, in fact, a self-styled voyeur who commands through the veil of his voyeurism. Gazing on his subordinates, he plays the part of voyeur by forcing them into the role of the feminine, passive, victim of the masculine gaze" (9). This demasculinization within a relationship clearly encoded as masculine (the Comitatus bond) would 
be horrifying to those familiar with it. The focus on Judith as a virgin rather than a widow marks her more closely as a peaceweaver; she is leaving her home community to enter a hostile one under the guise of being a tribute of peace, much like a peaceweaving bride in early medieval England. Furthermore, like the brides-to-be in Beowulf (Thryth and Freawaru), she is described as "beagum gehlæste, / hringum gehrodene" [adorned with bracelets / adorned with circlets ] (Judith lines 36-37). The conflict between Holofernes and Judith, then, seems to be very much about the conflict between lord and peaceweaver.

Erin Mullaly discusses the anxieties brought forth by these conflicting roles in her article "The Cross-Gendered Gift: Weaponry in the Old English Judith." Mullaly explains that there is critical unease about Judith: she is not a saint, but she is also not a Germanic war hero, rather, she moves between traditional warrior and traditional peaceweaver roles. Mulally writes,

Judith exhibits several types of power within the poem: the secular power she holds over the life of her political enemy, Holofernes; the social power she possesses in the Bethulian community from which she emerges; and the spiritual power entrusted to her by God and made manifest in her violence against her heathen enemy. She is a secular and sacred hero whose position is complicated by her sex but not diminished by it. The poet foregrounds Judith's participation in a masculine warrior culture's system of exchange while at the same time maintaining her image as a wise, gold-adorned woman. (257)

Judith exists as a figure who can do it all - she is able to perform idealized peaceweaving perfectly, but can immediately transition into warrior, and then move into being a leading lord, all while maintaining her spiritual power, as well. Holofernes, on the other hand, cannot do this maneuvering. He is unable to do anything other than what he is allowed to as a leading lord, a warrior. Lochrie explains that Holofernes is the image of hypertrophied masculinity, "a parody of the masculine ideals of governance, loyalty, fealty, and power, as well as the language that insures these ideals" (6). Lochrie argues that all of the things that mark his masculine power - his feasting, drinking, desire, self-indulgence - prove his undoing in their excess. Judith can 
transgress the boundaries of peaceweaving, whereas Holofernes cannot escape his masculine enclosure. Like Beowulf, who knows he must rely on his weapons in the end, would not wish to do so, if he "wiste hu wið ðam aglæcean ellse meahte / gylpe wiðgripan" [knew how else (he) could grapple with that combatant, with pride] (Beowulf lines 2521-22).

Holofernes cannot escape his masculine enclosure alive, at least. Mullaly explains that "Judith's transformation in the poem is not solely from passive to aggressive nor from 'feminine' to 'masculine,' but rather explicitly from 'possessed' to 'possessor.' Judith changes from an object to be possessed by a warrior, Holofernes, to the possessor of objects, Holofernes's head and the treasures with which she is subsequently rewarded" (257). Upon his death, Judith makes him into an object of exchange, and, like a peaceweaver, he is brought back to her community as a symbol of peace. Mulally argues that this allows Judith to enter a masculine cultural system of exchange, in which the goods and the exchange signify status. In other words, Judith harnesses her elusive femininity and accesses deadly masculinity to overtake and claim the spot in this system of exchange as a leading lord.

This is not done simply through killing Holofernes, but also through her relationships with objects, both weapons and more general treasures, in the poem, as well. Moments before the climax of the poem, Judith looks for a weapon to kill Holofernes with:

Pa wæs nergendes peowen prymful, pearle gemyndig hu heo pone atolan eaðost mihte ealre benæman ær se unsyfra womfull onwoce. Genam ða wundenlocc scyppendes mægð scearpne mece, scurum heardne, ond of sceaðe abræd swiðran folme (Judith lines 73-80)

[Then the glorious handmaid of the savior was severely mindful how she could most easily deprive that hateful one of life before that impure foul one awoke. And then the 
Creator's maiden with twisted hair drew that sharp sword, hard with storms, from that sheath with her right hand]

This moment is reminiscent of the moment Beowulf finds the ancient sword of giants in

Grendel's mother underwater hall:

Geseah ða on searwum sigeeadig bil, ealdsweord eotenisc ecgum pyhtig, wigena weorðmynd, pæt wæpna cyst, buton hit wæs mare ðonne ænig mon oðer to beadulace ætberan meahte, god 7 geatolic, giganta geweord.

He gefeng ba fetelhilt, freca Scyldinga hreoh 7 heorogrim, hringmæl gebrægd aldres orwena, yrringa sloh, pæt hire wið hales heard grapode, banhringas bræc (Beowulf lines 1559-69)

[He saw then among the armor a victorious blade, an ancient sword of giants strong in edges, worthy of warriors, that was the best of weapons, except that it was greater than any other man could carry to battle, good and ornamented, a work of giants. He seized then the linked sword-hilt, the warrior of the Scyldings, fierce and sword-grim, drew the ring-adorned sword, despairing of his life, angrily struck, so that hard one gripped her in the neck, broke her bone-rings.]

Beowulf and Judith both happen to see the swords they use to cut off the heads of their enemies, and in both of these instances God seems to play a role in them being able to see the weapons that bring them victory. Just before Beowulf sees the sword among the armor, the poet explains that God has decided he will emerge victorious. Similarly, as Judith looks for a way to kill Holofernes, she is repeatedly connected in language to God. These parallels seem to be purposeful - the binding of these two texts together suggests that the similarities were recognized.

While the two may be similar as warriors, Judith and Beowulf differ in how their stories end. While Beowulf succumbs to the treasure hoard, dying just outside its reach but looking within, Judith is able to claim the treasures of Holofernes' hoard for her people. Throughout this 
thesis, I have argued that much of Beowulf's downfall is caused by the agency of the treasures he must use both to maintain his men's loyalty and to fight his enemies. In his final battle, his sword, like Hrunting, fails him. Furthermore, the treasures he gave out to his men to ensure their loyalty fail to do so - his men, all except Wiglaf, abandon him in the hoard. Like Beowulf, Judith enters the enemy hoard only with one other person, her maidservant. However, she does not face any complications in regards to treasures failing her. In fact, much of her success can be traced to these treasure objects. Again, as Beowulf did with Grendel's mother, Judith was able to take up a sword she found within her enemies' home and use it against him. Unlike Hrunting, who did not wish to bite Grendel's mother, Holofernes' sword cut through Holofernes' neck with little difficulty, severing his head in two blows. While Holofernes' sword's agency is not of particular focus in this scene, Judith's ability to use his sword against him is nonetheless important, especially in the context of Beowulf which features episodes where the ability to use a weapon against an enemy is vital to the hero's outcome. Additionally, the golden net surrounding Holofernes' bed is an integral part of Judith's victory against him. That shimmering golden net, a treasure in and of itself, again, could be seen out of but not into. When Judith kills Holofernes, she is able to conceal her secret deed from Holofernes' men because of this special net. His death, enclosed in this golden treasure, is reminiscent of Beowulf's death at the entrance of the hoard, his last sight being the precious treasures within. Like Beowulf, Holofernes is unable to escape the treasure he coveted dearly.

Another important example of Judith's success with treasure objects can be traced to the actual clothing she was wearing. In the Latin Vulgate version of the text, part of what made her so beautiful to Holofernes was her clothing: "sandalia eius rapuerent oculos eius pulchritudo eius captivam fecit animam eius amputavit pugione cervicem eius" [her sandals ravished his eyes, her 
beauty made his soul her captive, with a sword she cut off his head. Trans: LatinVulgate.com] (Chapter 16 line 11). While in the Old English version, Judith's clothing is not specifically mentioned as a cause (perhaps due to the missing parts of the poem), her gold-adornment is focused on in key moments that indicate that they were heavily involved in her success. When she is brought to Holofernes' bed, for example, that is when she is first described as "beagum gehlæste, / hringum gehrodene" [adorned with bracelets / adorned with circlets ] (Judith lines 3637). Furthermore, after killing Holofernes and taking his head as a prize, Judith and her servant are again described as "beahhrodene" [ring-adorned] (Judith line 138). And, finally, once more, as Judith reveals her victory to her people via Holofernes' head, she is described as "golde gefrætewod" [adorned in gold] (Judith line 171). In these key moments, the reader is reminded of Judith's relationship with the treasure objects she wears. Perhaps commentary was being made on the closeness of the peaceweaver with treasure and hinting at the power that closeness brings.

If in Beowulf there was an attempt to control the danger of peaceweavers and the danger of treasures by combining them only when they were both doing what they were expected to do, then Judith is openly challenging that effort, tearing it apart as quickly as it was made. She is as effective as Grendel's mother in her ability to use her peaceweaving knowledge and skills to her advantage - she knows exactly who she must kill to bring the most pain to her enemies, and she does it. And, like Thryth, she uses her beauty to bring about Holofernes' death. While Thryth kills any man who looks at her, Judith weaponizes the male gaze, enchanting Holofernes in sight to bring him to his death. As Lochrie states, "Judith is able to refuse the gaze, to turn it back on itself, and to appropriate its violence" (9). But Judith also harnesses the power of idealized peaceweavers like Wealhtheow. In Beowulf, the women who keep the peace are the ones adorned in gold - they marry those outside of their community, and through politics, conversation, and 
wisdom, they must find a way to keep men's swords at rest. However, Judith takes these qualities, adorns herself in gold, and walks into the enemy camp as both a peaceweaving bride and a determined warrior. Mullaly writes, "she is a gold-adorned lady, who-like Wealhtheow, urgers warriors to action, but she is also militant, executing her people's greatest enemy" (256). Judith does not relegate herself only to peacemaking, but she takes the skills she has as a woman to bring her people to victory and herself to glory.

As with the treasures in Beowulf, there is an anxiety here about what the peaceweaver can accomplish when she decides not to use her power for men, but for herself. There is always the possibility that if she fails at weaving the bonds of peace, the negative consequences may only affect the man, the lord, and prove to instead be beneficial to the peaceweaver herself. As when Hrothgar reads the hilt, seeing both the glory of its ancient creators and the longevity of the thing that will outlive him and all those he knows, the reader of Judith can recognize a similar power in the peaceweaver. Like the hilt, Judith communicates many stories, the glory of God, triumph over invaders, but also a hidden threat to the masculine economy. If so much relies on both the peaceweaving wife and the peacemaking object - the loyalty of men, the success of the community, the alliances between nations, and the success of the following generations - then certainly, the possibility always remains that they might escape the masculine enclosure, becoming independent of men.

Even in idealized peaceweaving, we see this threat surface. Helen Conrad O'Briain discusses the influence of Wealhtheow in her chapter "Listen to the Woman: Reading Wealhtheow as Stateswoman," explaining that in Beowulf's last conversation with Hrothgar, his main focus is actually bargaining with Wealhtheow. Before this last conversation, she had commended her sons to Beowulf in an attempt to keep them safe from Hrothulf. Beowulf does 
not respond to her immediately, and never directly, however, as O'Briain writes, "Beowulf's last words are to Hrothgar are not to the king, but to the queen, promising her all she had asked in the most diplomatic of terms" (206). In his final words to Hrothulf, Beowulf promises that Hrethric will find many friends if he ever comes to the Geatish court, even though this is a request Wealhtheow made. This is important as, despite Hrothgar being the leader, as well as being the one Beowulf is directly bargaining with, Beowulf's final promises are made to Wealhtheow. This is a recognition on Beowulf's part that Wealhtheow is a true leader of the community, and a person he actually must make deals with, even though on the surface he must appear to be forming bonds with Hrothgar alone. Similarly, in Thryth's marriage to Offa, we see that Offa's success as a ruler is actually credited to her:

Đær hi syððan well in gumstole, gode mære lifgesceafta lifigende breac, hiold heahlufan wið hælepa brego, ealles moncynnes mine gefræge pæs selestan bi sæm tweonum, eormencynnes. Forðam offa wæs geofum 7 guðum, garcene man, wide geweorðod. Wisdome heold eðel sinne. (Beowulf Lines 1954-63)

[There she afterwards in the throne, famous for good, used well her life as ordered by fate while living, held high-love with the ruler of warriors, of all mankind as I have heard say, that of the best between the seas, of the human race. Therefore, Offa became, in gifts and in battles, the bold man, widely honored. He held his homeland in wisdom.]

Her excellence as a ruler is described, and then, "therefore," Offa became widely honored. Once more, when the woman is doing exactly as expected, performing idealized peaceweaving, she is presented as authorizing the lord, her husband.

In Judith, we see this possibility come to the forefront. She begins her journey under the guise of a passive peaceweaver, willingly exchanging herself to bring peace between her people 
and the enemy. Adorned in gold, she is much like a treasure to be exchanged: on the surface, to Holofernes, her intentions are the same as his; her agency is hidden. The outcome of the battle lies in her choices, though: and she chooses to protect her people and earn her glory, her true interests. She is not unlike the precious weapons of Beowulf; like Hrunting, her interests are unknown to the man who accepted her as a gift. Through Judith, we can see that the peaceweaver was like a powerful treasure, and that the anxiety exists that she may possess the power to overcome mankind, just as "Sinc eaðe mæg, / gold on grunde, gumcynnes gehwone / oferhigian, hyde se ðe wylle" [Treasure can easily, gold in the ground, overpower each of mankind, hide that who wishes] (Beowulf lines 2765-67). Perhaps, the gold-adorned peaceweaver, like the golden net around Holofernes' bed, similarly figures a glittering exterior and a profound threat within. 


\section{CONCLUSION}

In this project, I considered the question: What does it mean for a woman to be objectified if the object is agentive? This involved examining the agency of peaceweaving women through the lens of Object-Oriented Ontology, or the idea that objects have agency in ways that humans often cannot perceive. Early medieval English literature seems to have recognized the agency of both objects and objectified women seems to have been recognized. The portrayals of objects: swords, armor, and treasures more generally, indicated a fear about the ways in which objects of high value were necessary for the survival and success of the community (and the community's leading men), while also were incredibly threatening to the survival and success of the community (and, in particular, the community's leading men). This same duality applies to the peaceweaving woman; she was needed to maintain the peace and negotiate tension between men, but with the very same power came a threat: she could not keep the peace at all, instead weaving threads of violence. By examining the dualities of these women and treasures together, both in terms of their importance to men and their threat to men, I believe that a more complex understanding of peacemaking women and peacemaking objects in early medieval English literature can be reached.

In my first chapter, I bring these two topics together by discussing the connections between peaceweaving and treasure in early medieval England. In their movement of exchange from one community to another, both peaceweavers and treasure served their purpose in society: to create peace and ensure loyalty of thanes to their lord, thus building the security of the community. This role was clearly important and highly valued. As Megan Cavell and Helen Conrad O’Briain have shown, peaceweavers were associated with elevated social prestige, morality, and Christian piety. This value was attributed to the golden treasures the peaceweavers 
were adorned with as well: as Cavell explains, golden textiles and garments were associated with glory, creation, and fate, all lofty ideals. This association likely comes from the established use of treasures, especially golden treasures, as a primary agent of cohesion in the bonds between thanes and lords, and thus a vital aspect of society in the early medieval English period. Through marriage, peaceweaving women acted in the same way, moving between men to create partnerships between them. However, in this very same movement, they act as reminders on either side of the feud that caused the peaceweaver/maker to be required in the first place. The peacekeeper (whether wife or treasure) had to be brought into the community as one of its own, while also being remembered as a part of the community that they originally had conflict with. An impossibility in a society where "Oft seldan hwær / æfter leodhryre lytle hwile / bongar bugeð, peah seo bryd duge" [Continually, seldom anywhere after the death of a leader does the deadly spear rest even a little while, though the bride is good] (Beowulf Lines 2032-34). When the spear becomes active again and peace is lost, the peaceweaver loses her gold-adornment, as seen in the cases of Thryth before her marriage to Offa, the wife Ongentheow after her capture, and the women of Beowulf's community upon his death. Even though peace was recognized as fleeting by nature, women's associations with treasure were severed the moment they failed to perform their idealized peaceweaving roles. Perhaps, this removal was a method to control the threatening possibility of the power the two held together over men.

In chapter two, I shed light on this threatening possibility by moving into discussing Object-Oriented Ontology and its implications of agentive treasure objects. Through examinations of the rune-stick in Riddle 60 of the Exeter Book, Beowulf's corselet, and the sword Hrunting, we see an apparent necessity for consent on behalf of all parties (man and object) in order for the intended action of the man to be completed successfully. Furthermore, in 
both the rune-stick and the sword of giants that brings Beowulf his victory against Grendel's mother, objects were perceived as having an existence outside of their use to men. This frames the objects as independent of mankind, and as beings in their own right. This idea appears once more when we see the rune-stick and the giant's sword-hilt framed as communicators with speech-like abilities. In Old English, reordberend [speech-bearer] as a synonym for man, suggests one of the ways humans are classified, thus opening up the realm of possibilities for what can be considered human to include anything that can bear speech. Treasure was depicted as human-like once more in Beowulf in the much-discussed lines 168-169, in which treasure is written to have the ability to love and/or know a man's mind. Linguistically, this is important, as well. For, according to Beth Levin's English Verb Classes and Alternations, wisse [knew] is a See-verb, and See-verbs only take Agent-subjects - meaning that the subject must be rational and animate. This distinction also applies to when Hrunting refused to bite or attack Grendel's mother. However, the agency of treasure objects is also supported when instances of their personification are examined from the perspective of if their agency has consequences or not on the action. This can be seen in the actions of Hrunting, Beowulf's corselet, whose active participation determine the outcome of battle. Additionally, treasure object's actions entirely independent of men are shown as having consequences: when the treasure-hoard was left alone is when it had its greatest effect on the world around it by attracting the dragon. Their capacity for this independence forces us to confront the chaotic agency of these objects and recognize that, like men, they can withhold their help, no matter how much it is needed.

In chapter three, I begin by discussing the consequences of treasure objects' powerful agency. In light of Beowulf's multiple mishaps with his weapons, his treasures, the Beowulf poet and Beowulf himself express discomfort on their reliance on objects for success in battle and in 
life. Beowulf longs for a time when he could rely on his strength alone rather than the strength of his swords, and the Beowulf poet expresses that a warrior should rely on himself alone in order to succeed in battle. Even objects that were useful to Beowulf are threatening; the sword-hilt communicates to Hrothgar that Beowulf is monstrous, even though Beowulf intended for the hilt to serve as evidence of his glorious victory. Furthermore, the hilt reminds Hrothgar, and us as an audience, that individual objects are durable and stable, existing across the past, present, and future, a power that humans will never possess. This reminder comes in the form of the dragon's hoard of treasure, as well, which endures across multiple human generations and brings calamity in that existence. In the end, too, the treasure-hoard oferhigian [overpowers] Beowulf, his dying moments looking upon them and wishing for them to be distributed to his people, only for both him and the treasures to vanish in the end. When a thing does not behave as it is meant to, we feel threatened. Similarly, in Beowulf, when a peaceweaver does not behave as expected, she becomes threatening. This can be seen in both Grendel's mother and Thryth, who represent the fear of what could happen if peaceweavers escaped the confines of peaceweaving; much like the treasure-hoard, there is a fear that the peaceweaver might find she is capable of oferhigian [overpowering] men. This threat is fully realized in Judith, which represents concerns about the masculine economy, peaceweaving, and treasures within its biblical context. Judith is able to both escape and exist within the masculine economy, taking on the role of both peaceweaver and warrior. Her enemy, Holofernes, like Beowulf, cannot take on both roles, becoming imprisoned in the role of masculine warrior. Beowulf cannot claim the treasures he dies for, and he often times cannot get his treasures to cooperate towards his success. Judith, on the other hand, is both able to claim the treasures of her enemy at the end and is able to use treasures to her advantage to win her fight against Holofernes. Her golden-adornments, mentioned in key parts of the text 
(when she enters Holofernes' camp, takes Holofernes' head, and presents his head as a prize to her people), are tied to moments when she is able to both perform as a feminine peaceweaver and a masculine warrior: thus bringing her victory over men. These key moments provided commentary on the combined power of treasure and peaceweavers: if the success of men relies on both, then surely, the two can work together, turning against men. As women donned their intricate rings, Byzantine-style necklaces, and dazzling gold-encrusted fabrics (as discussed in Chapter One), they reminded men in power, their communities, and themselves that while they may look like treasures to be exchanged within the masculine economy, they may just as well escape that enclosure, finding success in a world of their own. 


\section{WORKS CITED}

Beowulf. Trans R.M. Liuzza. Ed. R.M. Liuzza. Broadview Editions, 2013.

Cavell, Megan. "Formulaic Fripuwebban: Reexamining Peace-Weaving in the Light of Old English Poetics.” Journal of English and Germanic Philology, 114.3, 2015, pp. 355-372. Web.

Conrad O’Briain, Helen. "Listen to the Woman: Reading Wealhtheow as Stateswoman" New Readings on Women and Early Medieval English Literature and Culture: CrossDisciplinary Studies in Honour of Helen Damico, edited by Helene Scheck and Christine E. Kozikowksi, Art Humanities Press, 2019, pp. 191-208.

Fee, Christopher, “'Beag and Beaghroden' Women, Treasure, and the Language of Social Structure in 'Beowulf,'” Neuphilologische Mitteilungen, 97, I3, 1996, pp. 285-294, https://www.jstor.org/stable/43346397

Fillmore, Charles J. "The Case for Case." Form and Meaning in Language. University of Chicago Press, 1968. 21-294. Web.

Harman, Graham. “An Outline of Object-Oriented Philosophy.” Science Progress (1933-), 96, 2, 2013, pp. 187-199.

Horner, Shari. "Voices From the Margins: Women and Textual Enclosure in Beowulf." The Discourse of Enclosure: Representing Women in Old English Literature. New York: State University of New York Press, 2001, pp. 65-100.

Jamison, Carol Parrish. "Traffic of Women in Germanic Literature: The Role of the Peace Pledge in Marital Exchanges." Women in German Yearbook, 20, 2004, pp. 13-36. http://libproxy.lib.ilstu.edu/login?url=https://search.ebscohost.com/login.aspx?direct=true $\& \mathrm{db}=\mathrm{edb} \& \mathrm{AN}=15579148 \&$ site $=$ eds-live $\&$ scope $=$ site 
Kiernan, Kevin, ed. "Electronic Beowulf 4.0 (Online Version).” British Library, 2015. Web.

Krapp, G.P, and E.V.K Dobbie, eds. "Riddle 60." The Exeter Book. New York: Columbia UP, 1936.

Levin, Beth. English Verb Classes and Alternations: A Preliminary Investigation. The University of Chicago Press. 1993. Print.

Lochrie, Karma. "Sexual Violence and the Politics of War in Old English Judith," Class and Gender in Early English Literature, 1994, pp. 1-18. Web.

Martin, T. F. "(Ad)dressing the Anglo-Saxon Body: Corporal Meanings and Artefacts in early England," The Chiming of Crack'd Bells: Recent Approaches to the Study of Artefacts in Archaeology, 2677, 2014, pages 27-38.

Michelet, Fabienne L. "Hospitality, Hostility, and Peacemaking in Beowulf.” Philological Quarterly 94.1/2, 2015, pp. 23-50. Web.

Mitchell, Bruce. Old English Syntax. Clarendon Press, 1987.

Mullally, Erin. "The cross-gendered gift: weaponry in the Old English Judith." Exemplaria, 17.2, 2005, pp. 255-284. Web.

Naismith, Rory. "The Economy of Beowulf." Old English Philology: Studies in Honour of R.D. Fulk. Boydell \& Brewer, 2016, pp. 371-391. Web.

Owen-Crocker, Gale. Dress in Anglo-Saxon England. Woodbridge: The Boydell Press, 2004.

Paz, James. “Æschere’s head, Grendel’s mother and the sword that isn’t a sword: Unreadable things in Beowulf," Nonhuman Voices in Anglo-Saxon Literature and Material Culture. Manchester University Press, 2017, pp. 34-58. Print. 
Paz, James. "The 'thingness' of time in the Old English riddles of the Exeter Book and Aldhelm's Latin enigmata," Nonhuman Voices in Anglo-Saxon Literature and Material Culture. Manchester University Press, 2017, pp. 59-97. Print.

Poems and Prose from the Old English. Trans. Burton Raffel. Ed. Burton Raffel and Alexandra H. Olsen. New Haven, Connecticut: Yale University Press, 1998. Print.

Price, Helen. "The Hoard Uncovered: Objects and the Ground as Poetic Ecosystems." Human and NonHuman in Anglo-Saxon and British Postwar Poetry: Reshaping Literary Ecology, University of Leeds, 2013, pp. 130-196. PhD Thesis.

Rissman, Lilia, and Asifa Majid. "Thematic Roles: Core Knowledge or Linguistic Construct?" Psychonomic Bulletin \& Review, 26.6, 2019, pp. 1850-1869. Web.

Robinson, Fred C. Beowulf and the Appositive Style. University Tennessee Press, 2014. Print. Roman, Christopher. “Thinking with the Elements: J.R.R. Tolkien’s Ecology and ObjectOriented Ontology.” Cormarë Series, 34, 2015, pp. 95-118. EBSCOhost, search.ebscohost.com/login.aspx?direct=true $\& \mathrm{db}=\mathrm{edb} \& \mathrm{AN}=117547571 \&$ site $=$ edslive \&scope $=$ site.

“The Book of Judith: Chapter 13" latinvulgate.com, http://www.latinvulgate.com/verse.aspx $? \mathrm{t}=0 \& \mathrm{~b}=18 \& \mathrm{c}=13$.

Unknown. (800-900). Gold Ring. London, England: Victoria and Albert Museum. http://collections.vam.ac.uk/item/O122080/ring-unknown/

Unknown. (Late $7^{\text {th }}$ Century). Desborough Necklace. Desborough, England. British Museum. https://research.britishmuseum.org/research/collection_online/collection_object_details.a spx?objectId=95936\&partId=1 
Duke William's daughter Aelfgyve is promised in marriage to King Harold II. Bayeux Tapestry, $11^{\text {th }}$ century, Erich Lessing Culture and Fine Arts Archive, akg-images. 